\title{
Repercussions of COVID-19 Pandemic and its Impact on Economies of the Arab Countries
}

\section{تداعيات جائحة كوفيا -9 1 وتأثتيرها على اقتصاديات الدول العربية}

د/ سالي محمد فريد

أستاذ مساعد - قسم السياسة والاقتصاد بكلية الدراسات الإفريقية العليا - جامعة القاهرة

الماخصن

تهدف الدراسة إلى التعرف على أثز كوفيد 19 على الدول العربية باستخدام نموذج

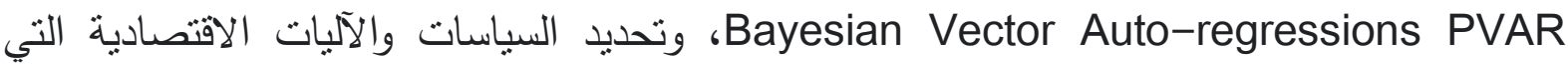

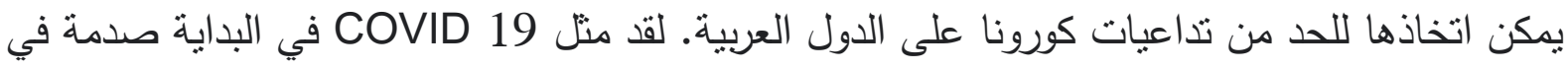
العرض، لكنه سرعان ما تحول إلى صدمة طلب، وأوضحت نتائج القياس أنه يؤدى إلى انخفاض العات العمالة

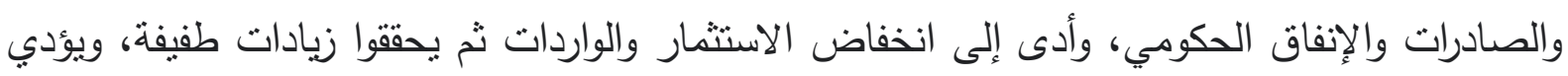

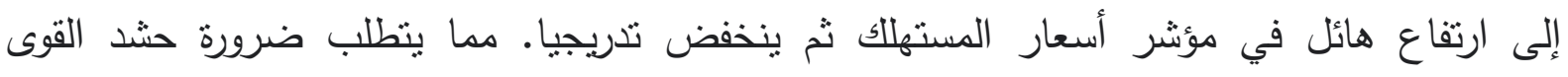

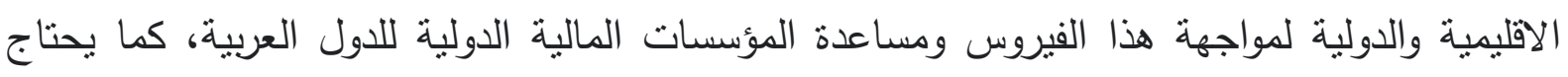

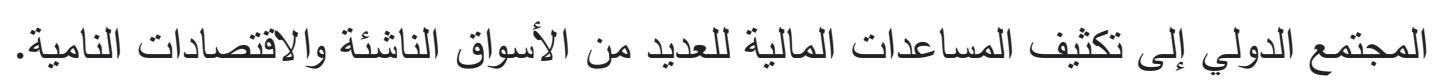

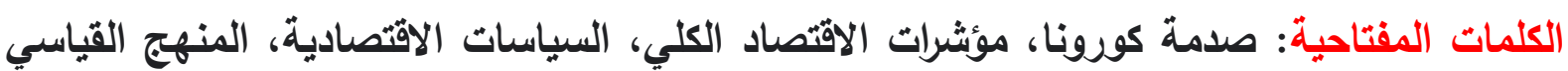

PVAR

\section{Abstract}

The study aimed at determines the impact of COVID 19 on the Arab countries using the Bayesian Vector Auto-regressions model PVAR, and determines the economic policies and mechanisms that can be taken to limit the repercussions of Corona on the Arab countries. The findings revealed the breakups of the Arab economies; COVID 19 was a supply shock in its first-time impact, but quickly trans-passes to demand shock. the pandemic effect decreases employment, exports and government expenditure, but investment and imports decline up then show a slight increase, and results a massive rise in consumer price index then a slight decrease. The study also relies on the SWOT Analysis method to analyze the repercussions of Coronavirus on economies of the Arab countries through analyzing the internal environment, by monitoring strengths and weaknesses, and analyzing the external environment by monitoring opportunities and threats. There is a necessity for a help of bilateral creditors and the international financial institutions for the Arab countries. The 
international community needs to intensify financial aid to many emerging market and developing economies.

\section{Keywords: Corona Shock, Macroeconomic Indicators, Economic Policies, Econometric Methodology PVAR.}

\section{Introduction}

The study aimed at examines the economic repercussions of Corona pandemic on the economic performance and macroeconomic indicators in the Arab countries. In addition to determine the economic policies and mechanisms that can be taken to limit the repercussions of Corona on the Arab countries.

The study measures impact of COVID-19 pandemic on the Arab economies in the short run. The pandemic effect is measured on macroeconomic variables like investment, employment, imports, exports, prices, and government expenditure using the Bayesian Vector Auto-regressions model PVAR. The study also relies on the SWOT Analysis method to analyze the repercussions of Coronavirus on economies of the Arab countries through analyzing the internal environment, by monitoring strengths and weaknesses, and analyzing the external environment by monitoring opportunities and threats.

\section{The Literature Review about Repercussions of COVID 19}

According to the statistics of the United Nations Industrial Development Organization (UNIDO), there is a decline in global industrial production, as global manufacturing growth has already slowed in 2020, and is expected to continue to decline due to the economic disruptions caused by the pandemic Corona. $^{212}$

The International Energy Agency report indicated the proportion of oil demand in China was 14\% of global demand in 2020, and the growth rate of oil demand in China accounted for more than $75 \%$ of the growth in global demand, so any setbacks to the Chinese economy was expected to have negative effects, indirectly to the global economy. The global oil demand declined in 2020 by 365,000 barrels per day, which is the worst demand performance since $2011 .^{213}$

The International Labor Organization ILO indicated that $81 \%$ of the global workforce was affected by the total or partial closure of the workplace in 2020. The global labor market loosed 200 million jobs, and 1.25 billion workers in the most sectors had affected by the pandemic, such as tourism, accommodation and food services, manufacturing industries, retail trade, business and administrative activities, which account about $38 \%$ of global employment. Also, ILO estimated the Corona pandemic impact on the total working hours during the second quarter of 2020 by approximately $10.5 \%$, compared to a decrease in the first quarter of 2020 by $4.5 \% .^{214}$ 
The International Civil Aviation Organization (ICAO) showed the aviation sector as one of the economic sectors most affected by the Corona pandemic, and estimated a significant decrease in the number of passengers during March 2020 compared to March 2019 by 54\%, so that Asia and the Pacific recorded the largest decrease by 85 million passengers, then Europe 50 million passengers, then North America about 35 million passengers. ${ }^{215}$

The International Monetary Fund estimated the cumulative loss of global GDP during 2020 and 2021 due to the COVID 19 pandemic about 9 trillion \$, which exceeds the GDP of Japan and Germany together, which are the third and fourth largest economies in the world, respectively. ${ }^{216}$

The United Nations Conference on Trade and Development (UNCTAD) indicated a decline in the global economic growth to less than $2 \%$ may add economic losses with trillion dollars, during March to June 2020. ${ }^{217}$

The economic slowdown affected on developing countries and laborexporting countries, including Egypt, have witnessed a slowdown in workers' remittances. In addition, slowing global economic growth and disruption of global trade are expected to have severe impacts on the supply side. Egypt, for example, depends on production inputs and imports raw materials, so negatively affected production rates and employment levels. ${ }^{218}$

A World Bank report estimated that remittances of Egyptian workers abroad declined by $21.5 \%$ during 2020 compared to a growth of 5\% in 2019 . The report indicated that remittances around the world decreased by 142 billion $\$$ in 2020, and remittances in the Middle East declined by $20 \%$ during 2020 compared to a growth of $2.6 \%$ in $2019 .^{219}$

The COVID-19 pandemic inflicted heavy and increased losses in various countries. The global economy witnessed a sharp contraction in 2020, which is much worse than the consequences of the global financial crisis of 2008-2009. The global economy is expected to grow with $5.8 \%$ in 2021 as economic activity returns to be normal, with support of economic policies. ${ }^{220}$

2. Analysis of the Economic Performance of the Arab Countries

The economic activity in a number of Arab countries was affected by the conditions of the global economic slowdown since the second quarter of 2019, which led to lower levels of external demand, in addition to the international oil prices was remaining at low levels. For example, the GDP growth rate in Saudi Arabia decreased from $1.7 \%$ in the first quarter of 2019 to $0.5 \%$ in the second quarter, the growth rate in Kuwait decreased from $0.9 \%$ to $0.4 \% .{ }^{221}$ 
Figure (1) GDP at constant prices for some Arab countries (2018/2019)

billions \$

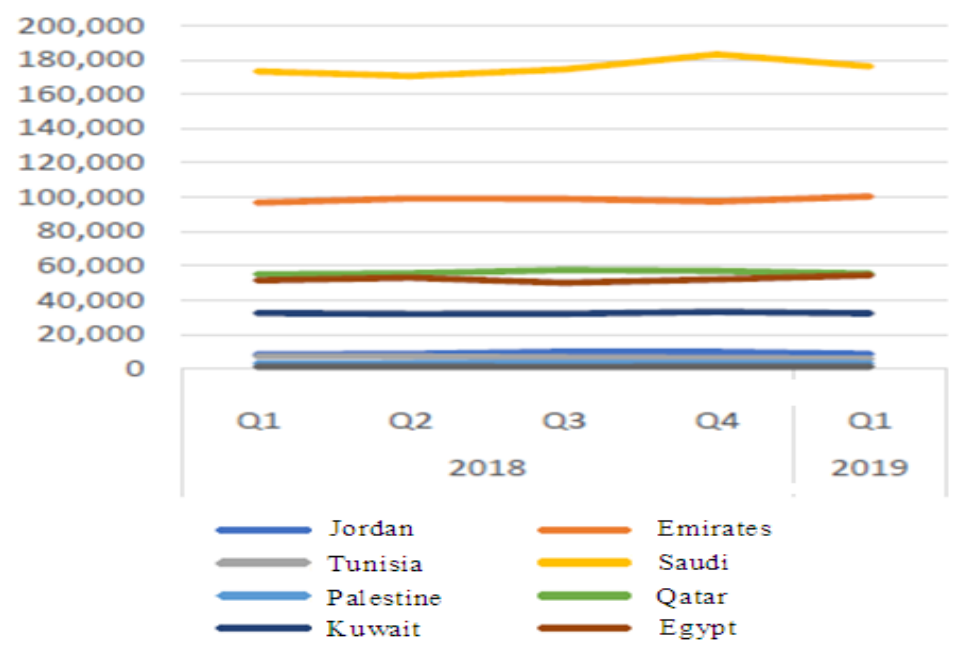

Source: The Arab Monetary Fund, https://www.amf.org.ae

The GDP growth rate increased slightly in Tunisia in the second quarter of 2019 to $2.1 \%$. The Egyptian economy grew by $5.3 \%$, representing the third highest economic growth rate recorded in the world after China and India. Jordan recorded a growth rate of $4.1 \%$ and emirates $3.7 \%$ in the first quarter of 2019. ${ }^{222}$

Figure (2) Forecasted growth rates of the Arab countries in 2021

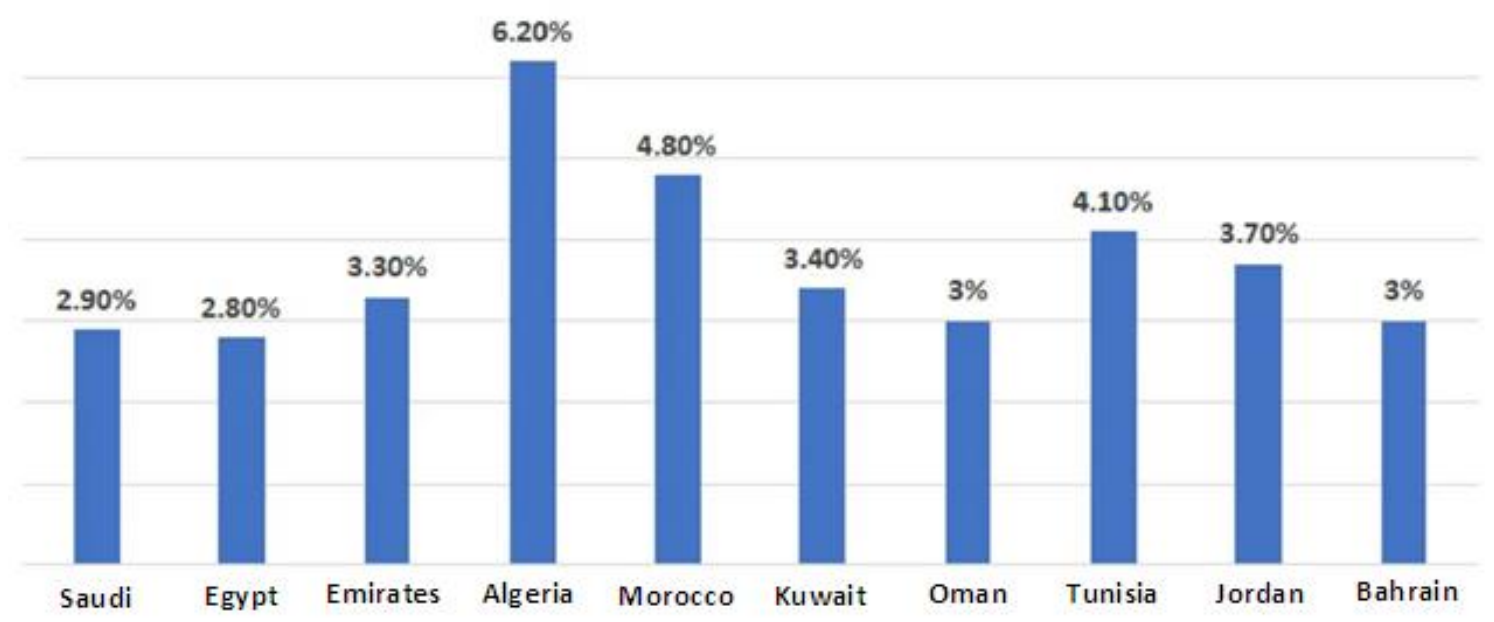

Source: International Monetary Fund: Considerations for Designing Temporary Liquidity Support to Businesses, (Washington DC, IMF, 2020)

The International Monetary Fund IMF expected Algeria to have a growth rate of $6.20 \%$ in 2021, followed by Morocco 4.80\%, Tunisia 4.10\%, Jordan 
3.70\%, Kuwait 3.40\%, then Emirates 3.30\%, Oman and Bahrain 3\%, Saudi Arabia $2.90 \%$, then Egypt 2.80\% (Figure 2).

Figure (3) Annual inflation rate in some Arab countries (\%)

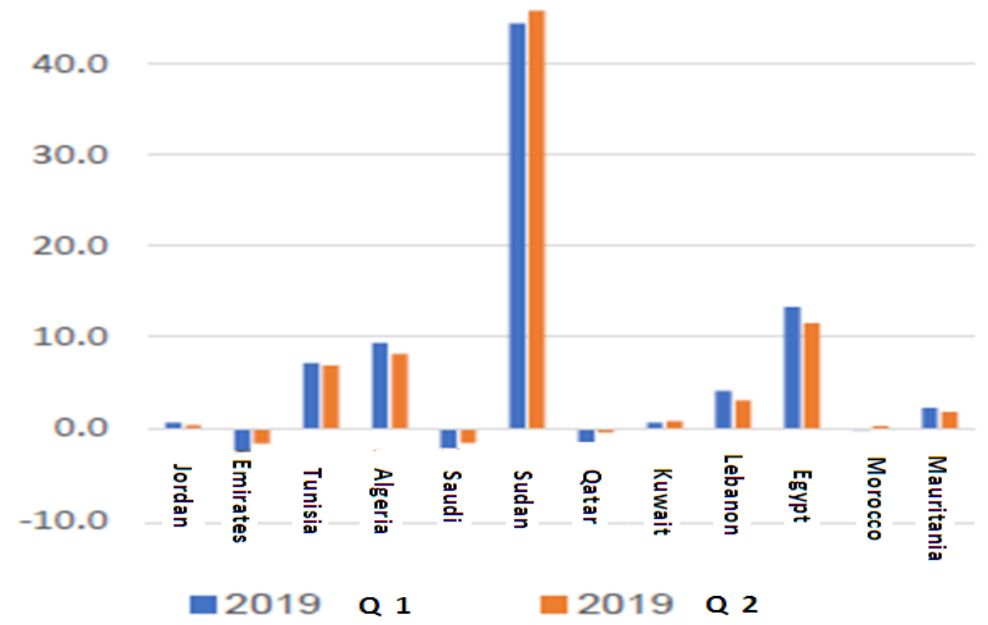

Source: The Arab Monetary Fund, https://www.amf.org.ae

The inflationary pressures declined in some of Arab countries, as Emirates, Saudi Arabia and Qatar, as a result of the slowdown in economic activity, implementing reforms to liberalize energy prices, and imposing new taxes to achieve fiscal discipline. On the other hand, the inflation rate recorded a significant increase in Sudan, by $45.8 \%$ with the continuing inflationary effects resulting from the inflationary financing of the budget deficit and the depreciation of the local currency against the dollar. In Jordan inflation rates raised slightly, reaching $0.8 \%$ in the second quarter, compared to $0.6 \%$ in the first quarter of 2019 (Figure 3).

Figure (4) Annual exchange rates of the flexible Arab currencies against dollar $\%$

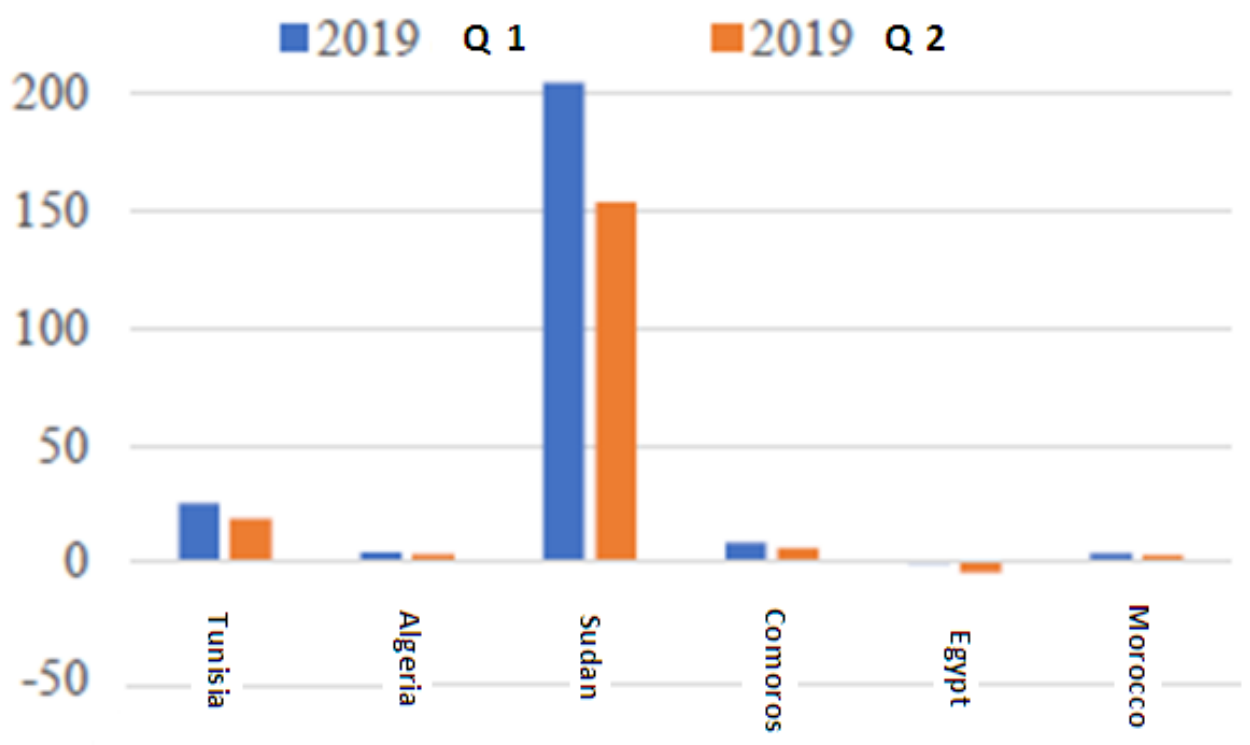


Source: The Arab Monetary Fund, https://www.amf.org.ae

The Sudanese pound recorded a significant decline against the dollar by $153 \%$ during the second quarter of 2019, reflecting the economic challenges facing the country and affecting the levels of foreign exchange supply. The Tunisian dinar fell against the dollar by $18.6 \%$ during the second quarter of 2019 , reflecting continued pressures on the external sector. The Moroccan dirham fell against the dollar by $2.8 \%$. On the other hand, the value of the Egyptian pound rose against the dollar by $4.4 \%$ during the second quarter, as a result of improved economic conditions and foreign exchange receipts in light of the reforms applied during the past years (Figure 4).

Figure (5) Unemployment rate in some Arab countries (2018-2019) \%

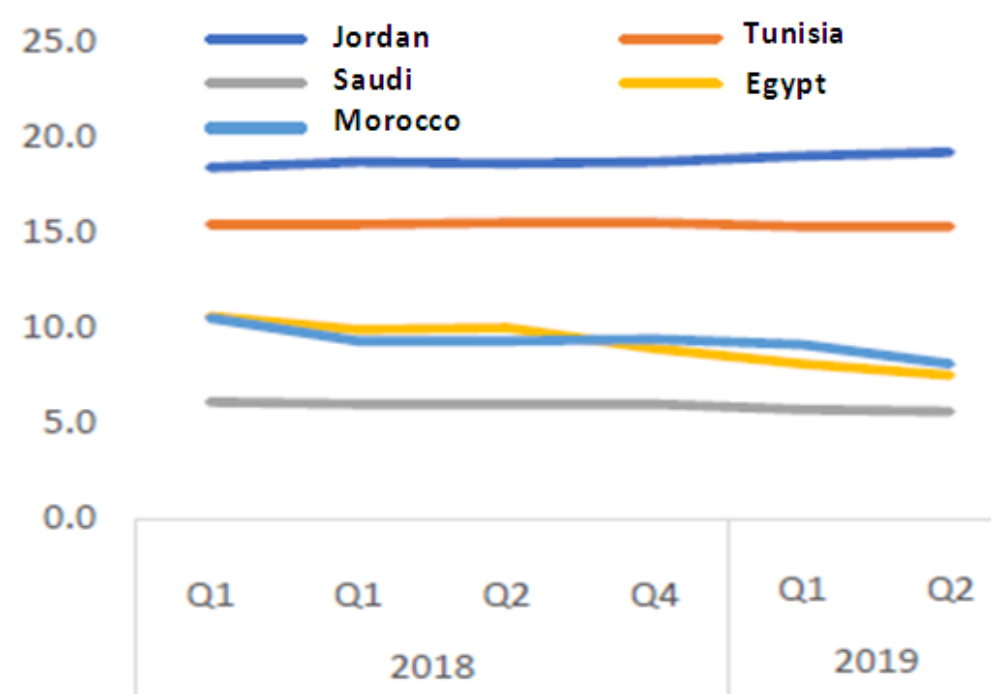

Source: The Arab Monetary Fund, https://www.amf.org.ae

The unemployment rate in Jordan rose to $19.0 \%$ during the first and second quarters of 2019, reflecting the slowdown in economic activity, compared to $18.4 \%$ and $18.7 \%$ recorded in the same two quarters of 2018 . The unemployment rate in Tunisia during the first and second quarters of 2019 was $15.3 \%$, On the other hand, unemployment rates recorded a remarkable decline in Egypt, reaching 8.1\% and 7.5\% during Q1 \& Q2 of 2019, which resulted in stimulating aggregate demand and creating more job opportunities. The unemployment rate in Saudi Arabia was 5.7\% and 5.6\% in 2019, which is attributed to the continued investment spending on projects included in the Kingdom of Saudi Arabia 2030 vision, in Morocco also decreased to 9.1 and $8.1 \%$ in 2019 (Figure 5). 
Figure (6) The growth rate of bank deposits and loans (\%) (Second quarter of 2019)

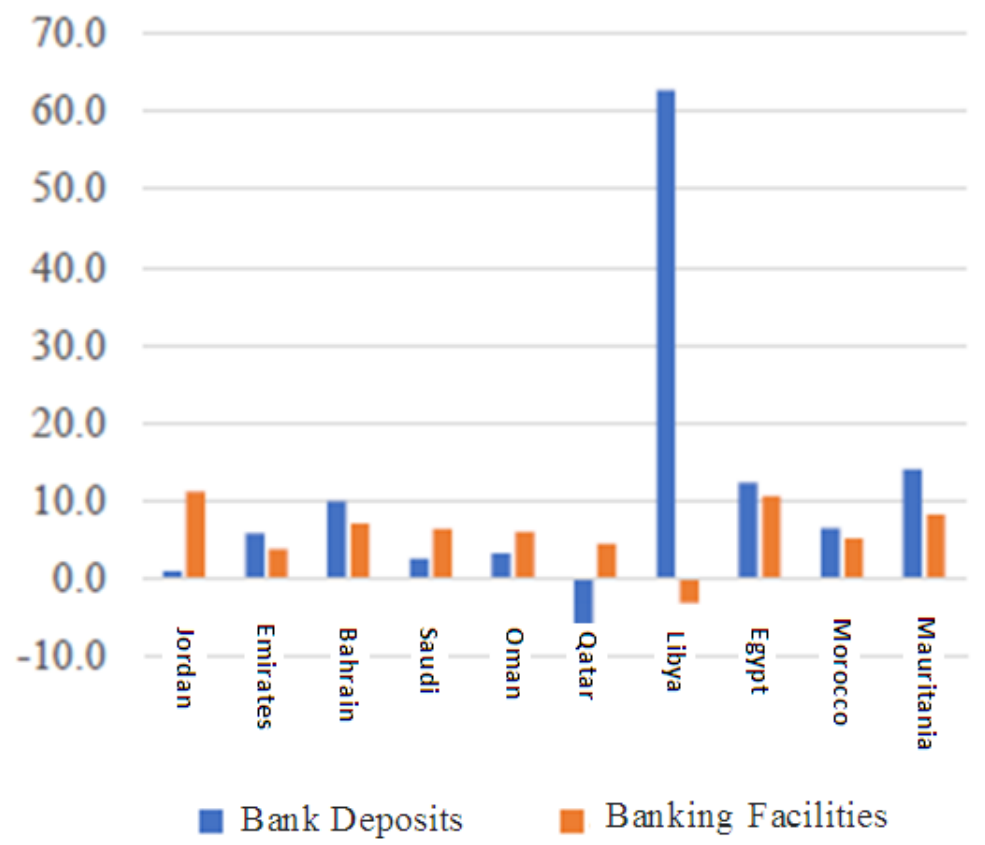

Source: The Arab Monetary Fund, https://www.amf.org.ae

Bank deposit levels improved in some Arab countries during the second quarter of 2019, as Libya recorded the highest growth rate of bank deposits, amounting to about 63\%. Also, bank deposits in Egypt increased by $12.3 \%$ in light of the growth recorded in the levels of output. Deposits in Iraq grew by $16.1 \%$. In contrast, bank deposits in Qatar decreased by $6.1 \%$ during the second quarter of 2019. With regard to loans and credit facilities, has improved in a number of Arab countries. The highest growth rates of loans and credit facilities were in Egypt with a growth rate of $10.6 \%$ during the second quarter of 2019, followed by Jordan by $11.1 \%$ and Bahrain by $7 \%$ (Figure 6).

The public revenues of three Arab countries recorded an increase, represented by Jordan, Qatar and Morocco, whose revenues grew by 4.3, 4.1 and $6.8 \%$, respectively, compared to the second quarter of 2018, while public revenues recorded a decline in Saudi Arabia, Oman and Mauritania, with a decrease in public revenues in these countries by 4.7, 3.1 and $11.6 \%$, respectively, during the second quarter of 2019. The public expenditures increased in four Arab countries during the second quarter of 2019, as Mauritania, Jordan, Qatar and Morocco increased by 10.3, 7.7, 7 and 3\%, respectively. While public expenditures recorded a decline in Oman by $11.1 \%$ during the second quarter of $2019 .{ }^{223}$

Table (1): The total Arab foreign trade during the period (2015-2019) 


\begin{tabular}{|c|c|c|c|c|c|}
\hline & 9.10 & $r .17$ & $r \cdot I V$ & $r \cdot 1 \Lambda$ & 2019 \\
\hline Arab exports & Iro., r & NTY & V9A & $907, \varepsilon$ & $1.90,5$ \\
\hline Arab imports & $9 \mu \cdot, 1$ & $\wedge \neg \leq, r$ & 111,1 & $\Lambda \cdot \wedge, \wedge$ & $\Lambda r \varepsilon, T$ \\
\hline Global exports & 11940 & $17 \leq \Lambda Y$ & 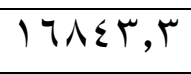 & IVVT. & $1911 \cdot, 7$ \\
\hline Global imports & $19 \cdot r \leq$ & 17V77 & 18179,9 & $11 \cdot Y \leqslant$ & $19 \leq .9, V$ \\
\hline $\begin{array}{l}\text { The ratio of Arab } \\
\text { exports to global } \\
\text { exports }\end{array}$ & 7,7 & $0, Y$ & $\varepsilon, V$ & $0, \Sigma$ & $0, V$ \\
\hline $\begin{array}{l}\text { The ratio of Arab } \\
\text { imports to global } \\
\text { imports }\end{array}$ & $\varepsilon, 9$ & $0, r$ & $\varepsilon, V$ & $\varepsilon, 0$ & $\varepsilon, r$ \\
\hline
\end{tabular}

Source: The Arab Monetary Fund, the Economic Outlook report 2020, www.atfp.org.ae

The value of total Arab merchandise exports increased to 1095.4 billion $\$$ in 2019, compared to 956.4 billion $\$$ in 2018, the total Arab merchandise imports increased in 2019 to 824.6 billion $\$$, compared to 808.8 billion $\$$ in 2018 (Table 1).

Figure (7) Arab exports and imports from the important trading partners in 2019
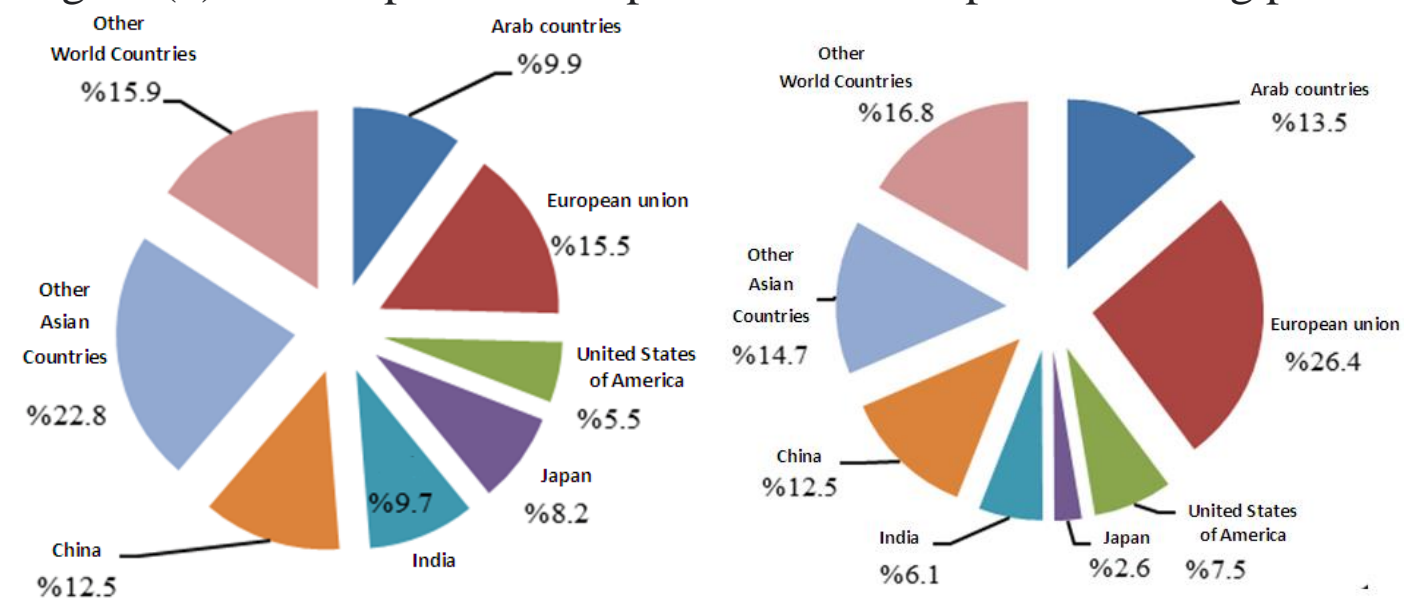

Source: The Arab Monetary Fund, the Economic Outlook report 2020, www.atfp.org.ae

Arab exports increased for important trading partners. Intra-Arab exports occupied 9.9\% of total Arab exports, the United States 5.5\%, the European Union 15.5\%, and Asia 53.2\%, while the rest of the world is about $15.5 \%$. The Arab imports increased from most trading partners by $1.0 \%$, Intra-Arab imports amounted $13.5 \%$ of total Arab imports, the United States recorded 7.5\%, and the European Union 26.4\%, as well as Asia 35.9\%, while the rest of the world is about $16.8 \%$, (Figure 7). 
Figure (8) the commodity structure for Arab exports and imports in 2019 Exports Structure (\%)
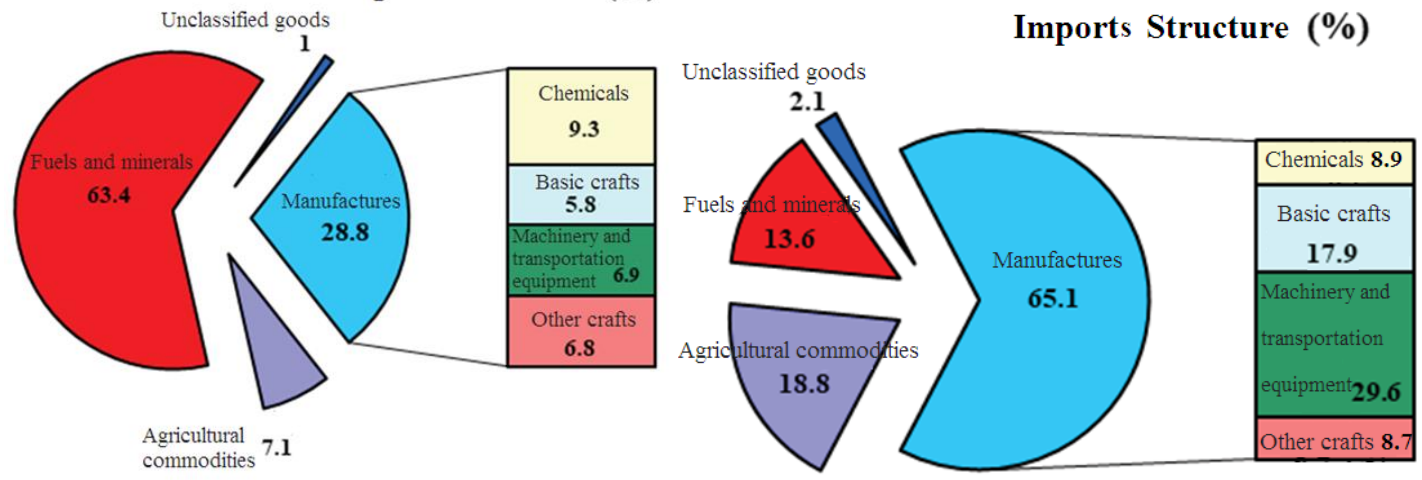

Source: The Arab Monetary Fund, the Economic Outlook report 2020, www.atfp.org.ae

The fuel and minerals occupied the largest share of total Arab exports, about $63.4 \%$ in 2019 , and manufactures recorded $28.8 \%$ of total exports. With regard to imports, manufactures amounted $65.1 \%$, while agricultural commodities achieved 18.8\% of total Arab imports during 2019 (Figure 8).

The value of Intra-Arab trade reached $6.2 \%$ of total Arab trade, about 10.6 billion $\$$ in $2019 .{ }^{224}$

Figure (9) the commodity structure for intra-Arab exports and imports in 2019
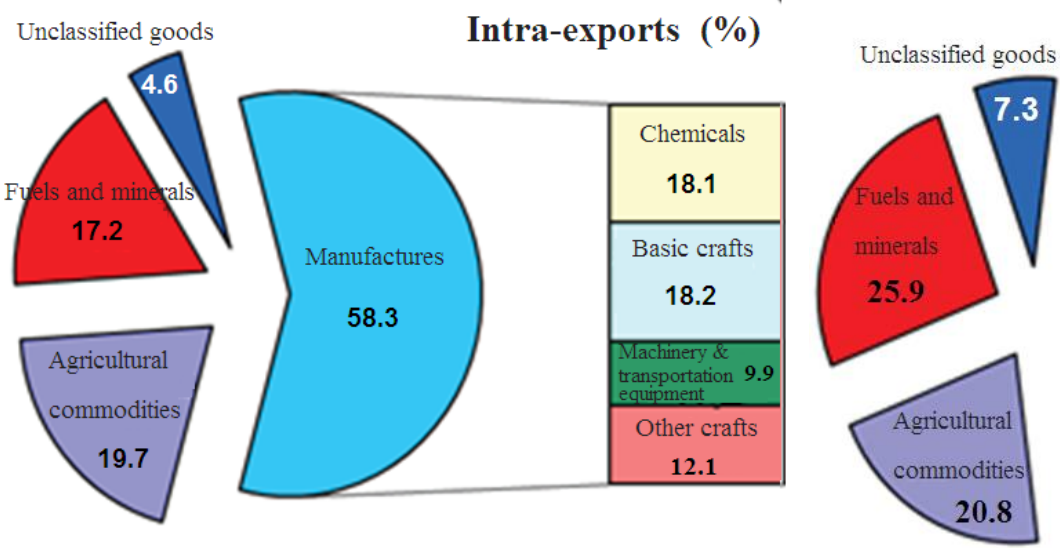

Intra-imports (\%)

Source: The Arab Monetary Fund, the Economic Outlook report 2020, www.atfp.org.ae

Fuel and minerals presented $17.2 \%$ of intra-Arab exports, the manufactures commodities acquired $58.3 \%$, and the agricultural commodities $19.7 \%$. With regard to intra-Arab imports, fuel and minerals presented $25.9 \%$ of intra-Arab imports; the manufactures $46.2 \%$ and the agricultural commodities 20.8\% (Figure 9).

\section{Analyses of COVID 19's Impact on the Arab Countries}

The COVID 19 pandemic has caused economic impacts on the Arab economy, through short and long-term repercussions, on the health, agriculture, food and trade sectors, according to a report issued by the League of Arab States. The International Monetary Fund indicated the economies of Arab 
countries to shrink by $5.7 \%$ in 2020 , due to the Corona pandemic, the drop in oil prices, and the closure of economic activities for about 3 months. ${ }^{225}$

a- The Impact on Economic Growth

ESCWA estimated the Arab countries losses of the pandemic as follows: Loss of 420 billion $\$$ from market capital (8\% of the wealth of Arab countries); Loss of 63 billion \$ of GDP's Arab countries; additional debts of 220 billion \$ (equivalent to $8 \%$ of GDP's Arab countries); loss of 550 million \$ per day in oil revenues if oil prices remain between 25-30 \$ per barrel; 28 billion $\$$ in exports; more than 2 billion $\$$ in revenue from tariffs and lost about 1.7 million jobs in $2020 .^{226}$

According to the Arab Monetary Fund, the Arab economies witnessed a recession during 2020 and a more shortage of public budget as a percent of GDP with high levels of public spending and a decline in oil and tax revenues. ${ }^{227}$

The productive services sectors in the Arab countries were affected by corona virus, especially tourism, transportation, internal and external trade and the manufacturing industry. These sectors are responsible for generating about $40 \%$ of the GDP in the Arab countries. ${ }^{228}$

b- The Impact on Oil Sector

The Corona pandemic led to sharp decline in oil prices, loosed oil revenues in the Arab region, with a net value of 11 billion \$, during the period from January to March 2020. The profits of oil-importing Arab countries derived from these prices was negligible compared to the losses of the oil exporting Arab countries. ${ }^{229}$

c- The Impact on Commodity Market

Table (2) The rise in commodity prices as a result of COVID 19 in a number of Arab countries

\begin{tabular}{|c|c|c|c|c|}
\hline & $\begin{array}{l}\text { Personal } \\
\text { care items }\end{array}$ & $\begin{array}{l}\text { medical } \\
\text { prevention }\end{array}$ & $\begin{array}{l}\text { basic goods } \\
\text { and services }\end{array}$ & $\begin{array}{l}\text { food and } \\
\text { beverages }\end{array}$ \\
\hline Iraq & $\% r$. & $\% 0$. & & $\% 1$. \\
\hline Jordan & & $\% 1 \ldots$ & & $\%$ \%. \\
\hline Sudan & $\% 1 \ldots$ & $\%$ \%... & $\%$ ro & $\% \Gamma$. \\
\hline Tunisia & $\%{ }^{\wedge}$ & $\% \mathrm{~V}$ & $\% 1$. & $\%^{\circ}$ \\
\hline Emirates & $\%$ \%. & $\%$ ro & $\% 0^{\circ}$ & $\% 1$. \\
\hline Qatar & & \%YO_Y. & & \\
\hline
\end{tabular}




\begin{tabular}{|l|l|}
\hline Palestine & There are no regular price changes \\
\hline Bahrain & The government forbade changing prices \\
\hline Saudi & The government forbade changing prices \\
\hline
\end{tabular}

Source: International Monetary Fund: Consumer Price Index in Response to COVID-19, (Washington DC, IMF, 2020)

The commodity prices rose as a result of COVID 19 in a number of countries, including Iraq, Jordan, Sudan, Tunisia, Emirates and Qatar, where the rate of increase in Sudan reached 30\% for food commodities and 200\% for medical protection goods. Saudi Arabia and Bahrain have taken decisions to prevent price hikes (Table 2).

d- The Impact on Labor Market

The International Labor Organization indicated the impact of COVID-19 pandemic on labor markets around the world with high unemployment, and the pressure increased on the private sector that were forced to close their business and lay off Employees and workers. The sectors of health care and food security, oil, tourism, and air transport affected by the crisis. ${ }^{230}$

The International Monetary Fund estimated the decrease in working hours around the world as follows:

- Africa: The decrease in working hours during the second quarter of 2020 was $9.6 \%$ compared to a decrease of $1.6 \%$ in the first quarter of 2020.

- United States of America: The decrease in working hours during the second quarter of 2020 was $12.4 \%$ compared to a decrease of $1.3 \%$ in the first quarter of 2020.

- Arab Countries: The decrease in working hours during the second quarter of 2020 was $10.3 \%$, compared to a decrease of $1.8 \%$ in the first quarter of 2020.

- Asia-Pacific: The decrease in working hours during the second quarter of 2020 was $10.0 \%$ compared to a decrease of $6.5 \%$ in the first quarter of 2020.

- Europe and Central Asia: The decrease in working hours during the second quarter of 2020 was $11.8 \%$ compared to a decrease of $1.9 \%$ in the first quarter of $2020 .^{231}$

The High unemployment rates, as a result of the damage in a number of economic sectors that provide employment opportunities because of corona virus, especially the tourism sector, which every direct job opportunity contributes to create five other indirect jobs. The Arab countries lost 1.7 million jobs by the end of $2020 .^{232}$ 
The remittances of workers abroad decreased in the Arab countries, which generate pressure on local currencies, and increase the cost of paying interest on foreign debt. ${ }^{233}$

e- The Impact on Tourism Sector

The Arab Tourism Organization and the Arab Civil Aviation Organization indicated the tourism and aviation sectors lost about 46 billion $\$$ as a result of corona crisis, in addition to the loss of one million jobs and thousands of seasonal jobs in the Arab countries. ${ }^{234}$

Table (3) Tourism revenues in the Arab countries (2019-2020) billions \$

\begin{tabular}{|c|c|c|}
\hline Countries & $r .19$ & $r \cdot Y$. \\
\hline Emirates & KY,O & $11, r$ \\
\hline Saudi & $1 \varepsilon$ & $V$ \\
\hline Egypt & IY,O & $7, Y$ \\
\hline Morocco & $\Lambda, \xi$ & $\varepsilon, Y$ \\
\hline Lebanon & $9, r$ & $\varepsilon, 7$ \\
\hline Jordan & 0,1 & $r, 9$ \\
\hline Bahrain & $r, v$ & 1,1 \\
\hline Tunisia & $r, \Sigma$ & $1, r$ \\
\hline Oman & $r$ & 1 \\
\hline
\end{tabular}

Source: World Travel and Tourism Council (WTTC), www.wttc.org

The tourism revenues decreased in emirates from 22.5 billion $\$$ in 2019 to 11.2 billion $\$$ in 2020, in Saudi Arabia decreased from 14 billion $\$$ to 7 billion \$, in Egypt decreased from 12.5 billion $\$$ to 6.2 billion $\$$, in Morocco decreased from 8.4 billion $\$$ to 4.2 billion $\$$, in Lebanon decreased from 9.3 billion $\$$ to 4.6 billion $\$$, in Jordan decreased from 5.8 billion $\$$ to 2.9 billion $\$$, in Bahrain decreased from 3.7 billion $\$$ to 1.8 billion $\$$, in Tunisia decreased from 2.4 billion $\$$ to 1.2 billion $\$$, and in Oman decreased from 2 billion $\$$ to 1 billion $\$$ in 2020 (Table 3). 
Figure (10): The impact of Corona on the tourism sector

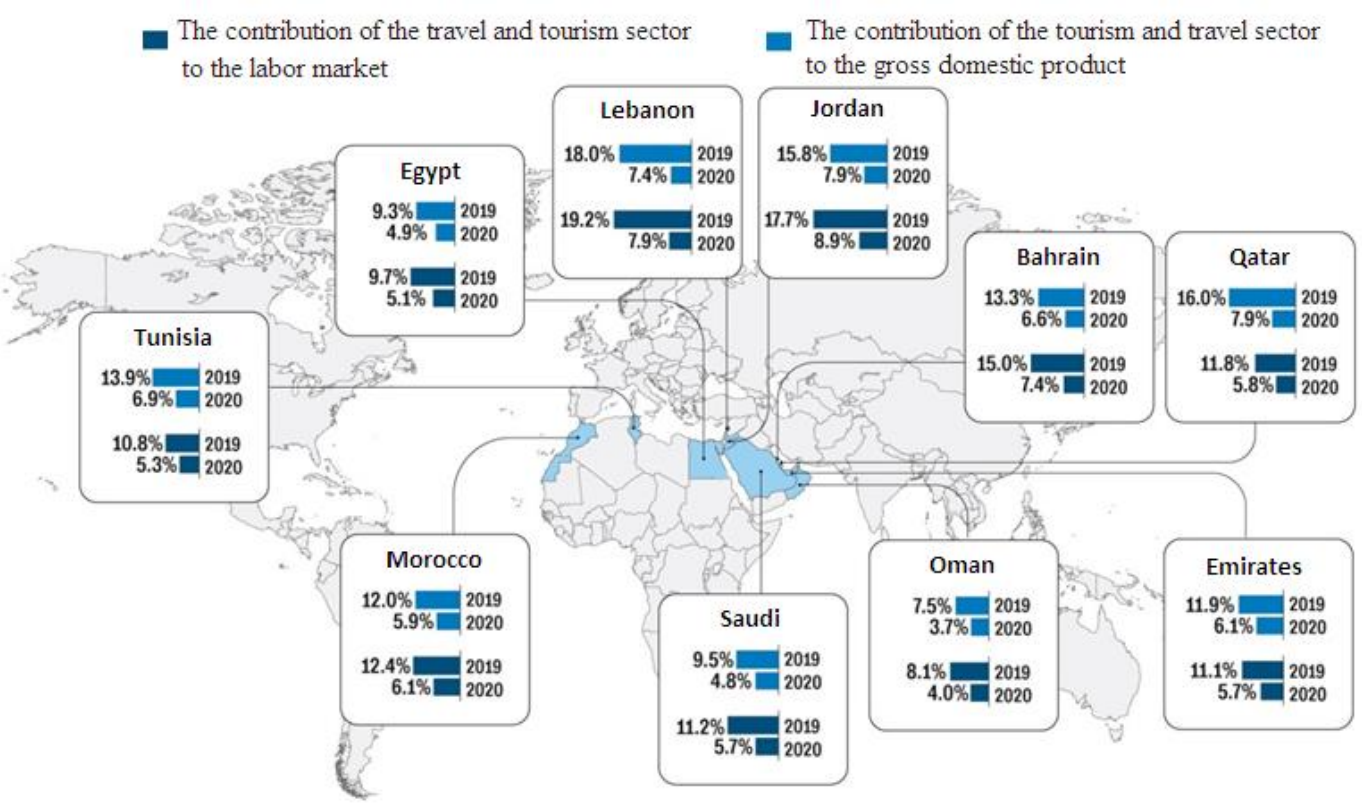

Source: World Travel and Tourism Council (WTTC), www.wttc.org

The Arab countries had a decrease in contribution of tourism and travel sector to the GDP and the labor market in 2020 compared to 2019 (Figure 10). Figure (11): Corona's impact on the tourism sector compared to other crises

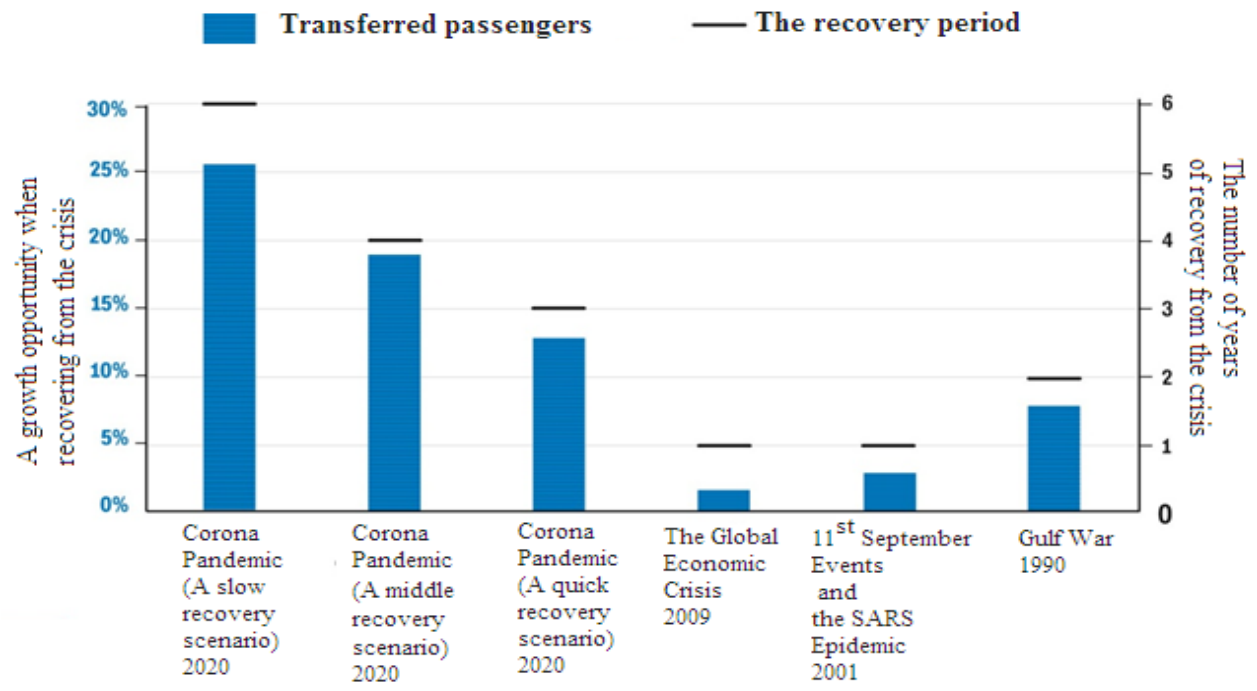

Source: the Arab Organization for Tourism, https://www.arabtourismorg.org

Figure 11 indicates impact of the Corona pandemic on the tourism sector, compared to other crises, such as the global economic crisis, where the recovery period ranges from 3 to 6 years, and this is considered as the longest crises.

f- The Impact on Aviation Sector

The International Air Transport Association (IATA) revealed that the sector suffered losses in all countries as a result of the suspension of air traffic, for example Saudi lost about 7.2 billion \$, and 287,500 jobs at risk, the 
estimated damage in the economy about 17.9 billion $\$$. Whereas the losses in Emirates amounted to 6.8 billion $\$$, and 287,700 jobs at risk, the estimated damage in the economy amounted to 23.2 billion $\$$. The losses in Egypt reached 2.2 billion \$, and 279,800 jobs at risk, the estimated damage in the Egyptian economy amounted to 3.3 billion $\$ .^{235}$

Figure (12) Corona's impact on the aviation sector in the Arab countries

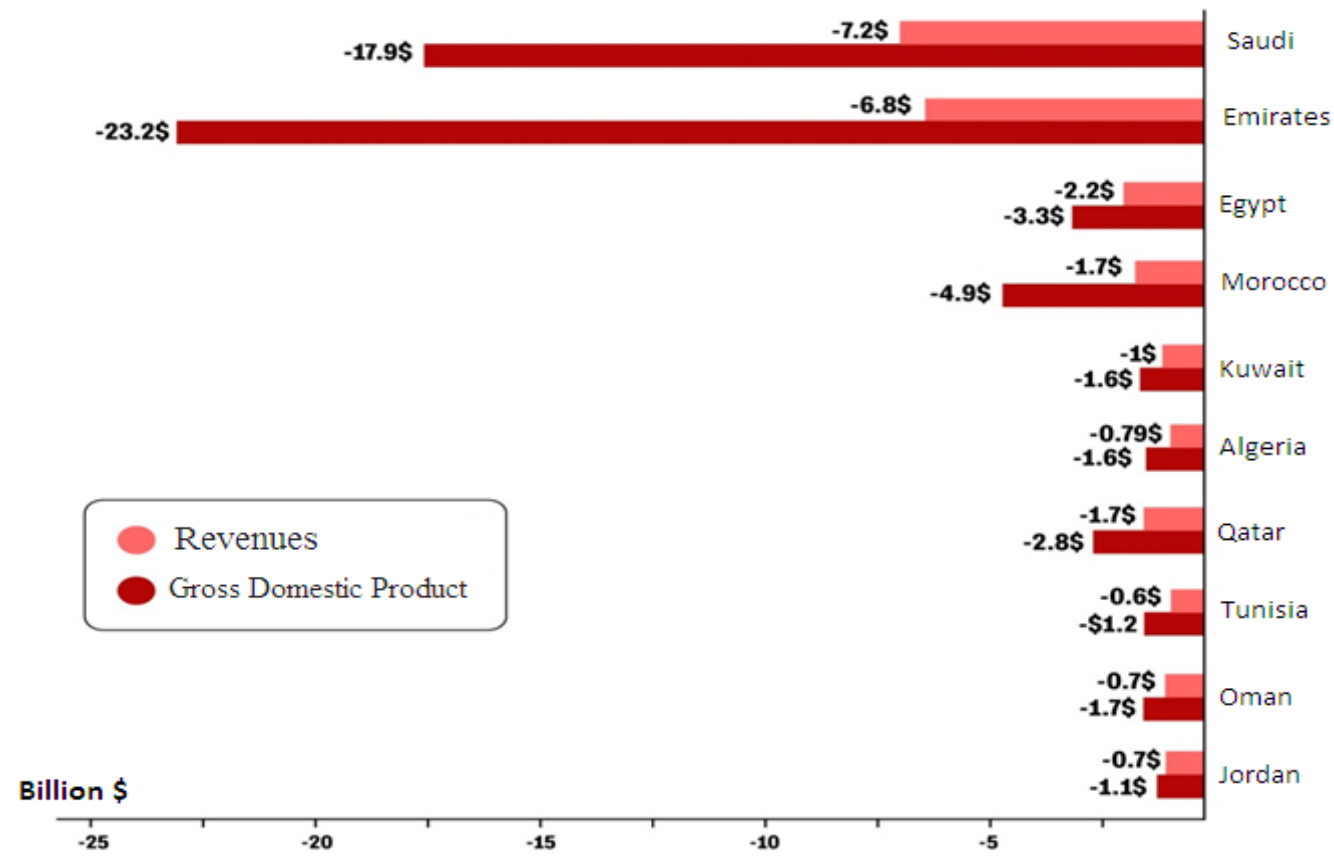

Source: The International Air Transport Association (IATA), www.iata.org The Corona pandemic reduced the GDP in Emirates by 23.2 billion $\$$, and the revenues of the aviation sector decreased by 6.8 billion $\$$, followed by Saudi Arabia, where GDP decreased by 17.9 billion $\$$, and the aviation sector revenues decreased by 7.2 billion $\$$, then Morocco, where GDP decreased by 4.9 billion $\$$, and the revenues of the aviation sector decreased by 1.7 billion $\$$, followed by Egypt, where GDP decreased by 3.3 billion $\$$, and the revenues of the aviation sector decreased by 2.2 billion $\$$. They followed by the rest of the Arab countries, Qatar, Oman, Kuwait, Algeria, Tunisia, and Jordan (Figure 12). Figure (13): The impact of Corona on passengers and jobs in the aviation sector 
The rate of decrease in the number of passengers

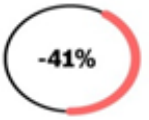

Kuwait

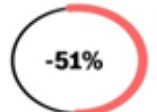

Morocco

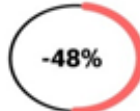

Oman

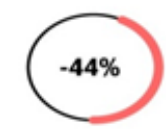

Tunisia

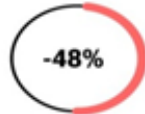

Egypt

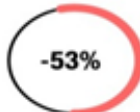

Emirates
Saudi

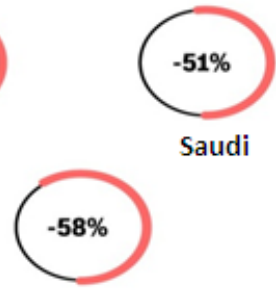

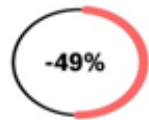

Qatar

Algeria

Number of jobs affected in the aviation sector

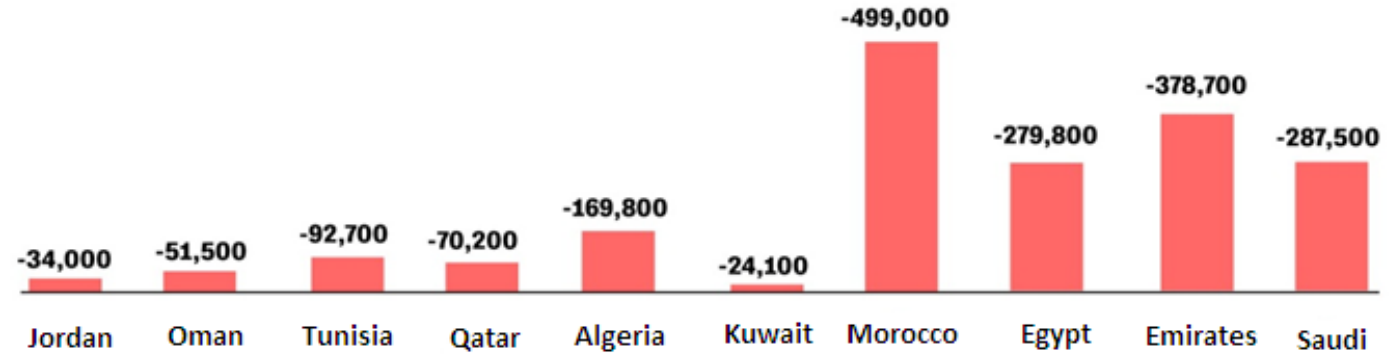

Source: The International Air Transport Association (IATA), www.iata.org

The number of travelers decreased in the Arab countries due to the Corona pandemic, as Algeria was the most affected Arab country, the number of travelers decreased by 58\%, followed by Emirates decreased by 53\%, then Saudi Arabia and Morocco by 51\%, Qatar 49\%, then Algeria, Egypt and Oman $48 \%$, Tunisia $44 \%$, and Kuwait $41 \%$. The number of jobs in the aviation sector was affected as Morocco, where 499,000 jobs reduced, followed by Emirates about 378,700 jobs, Saudi Arabia 287,500 jobs, then Egypt 279,800 jobs, Algeria 169,800 jobs, followed by Tunisia, Qatar, Oman, Jordan, and Kuwait (Figure 13).

4- The Impact on Foreign Trade

The exports of Arab countries were affected by declining in global demand $50 \%$, which was responsible for $48 \%$ of GDP, in addition to decline in oil and non-oil exports. The most important trading partners of Arab countries absorb $65 \%$ of Arab exports. The International Monetary Fund indicated the foreign trade of Arab countries declined significantly in 2020 due to the collapse in oil prices, as oil represents about $64 \%$ of total Arab exports, which affected the performance of intra-Arab trade. So, the surplus recorded in the balance of payments of Arab countries during the year 2019 turned into a deficit of $0.6 \%$ of GDP during $2020 .^{236}$

As a result of the global economic slowdown, exports of the Arab region decreased by 28 billion $\$$, which threatened the viability of export-dependent 
companies and industries. Companies in the Arab countries recorded losses in market capital, amounting to 420 billion $\$$ during the period from January to March 2020, and losses in the wealth of these companies were $8 \%$ of the total wealth of Arab countries. ${ }^{237}$

5- The Impact on Poverty

There are 101.4 million people under the poverty line in the Arab countries, because the food production, supply, transport and distribution chains were negatively affected by corona pandemic. This led to a decrease in food exports from food-producing countries, which affected food security in many Arab countries, due to their heavy dependence on food imports, especially basic foodstuffs, as they import $65 \%$ of the wheat they need, and spend about 110 billion $\$$ on food imports. The Corona pandemic threatened 55 million people in need of humanitarian aid in the Arab region, whether it was related to food, water, sanitation, medical supplies or health services. ${ }^{238}$

4- Measure the Impact of COVID 19 on the Arab Countries

The study measured impact of COVID 19 pandemic on the Arab economies in the short run. The pandemic effect is measured on macroeconomic variables like investment, employment, imports, exports, prices, and government expenditure using the Bayesian Vector Auto-regressions model (BVAR), which is linear multivariate time-series model to capture the joint dynamics of multiple time series.

PVAR Model:

COV19 $=\mathrm{C}(1,1) * \mathrm{COV} 19(-1)+\mathrm{C}(1,2) * \mathrm{COV} 19(-2)+\mathrm{C}(1,3) * \mathrm{CPI}(-1)+$ $\mathrm{C}(1,4) * \mathrm{CPI}(-2)+\mathrm{C}(1,5) * \mathrm{EMP}(-1)+\mathrm{C}(1,6) * \mathrm{EMP}(-2)+\mathrm{C}(1,7) * \mathrm{EX}(-1)+$ $\mathrm{C}(1,8) * \mathrm{EX}(-2)+\mathrm{C}(1,9) * \operatorname{GOVEXP}(-1)+\mathrm{C}(1,10) * \operatorname{GOVEXP}(-2)+$ $\mathrm{C}(1,11) * \mathrm{IM}(-1)+\mathrm{C}(1,12) * \operatorname{IM}(-2)+\mathrm{C}(1,13) * \operatorname{INV}(-1)+\mathrm{C}(1,14) * \operatorname{INV}(-2)+$ $\mathrm{C}(1,15)$

$\mathrm{CPI}=\mathrm{C}(2,1) * \mathrm{COV} 19(-1)+\mathrm{C}(2,2) * \mathrm{COV} 19(-2)+\mathrm{C}(2,3) * \mathrm{CPI}(-1)+$ $\mathrm{C}(2,4) * \mathrm{CPI}(-2)+\mathrm{C}(2,5) * \mathrm{EMP}(-1)+\mathrm{C}(2,6) * \mathrm{EMP}(-2)+\mathrm{C}(2,7) * \mathrm{EX}(-1)+$ $\mathrm{C}(2,8) * \mathrm{EX}(-2)+\mathrm{C}(2,9) * \mathrm{GOVEXP}(-1)+\mathrm{C}(2,10) * \operatorname{GOVEXP}(-2)+$ $\mathrm{C}(2,11) * \mathrm{IM}(-1)+\mathrm{C}(2,12) * \mathrm{IM}(-2)+\mathrm{C}(2,13) * \operatorname{INV}(-1)+\mathrm{C}(2,14) * \operatorname{INV}(-2)+$ $\mathrm{C}(2,15)$

$\mathrm{EMP}=\mathrm{C}(3,1) * \mathrm{COV} 19(-1)+\mathrm{C}(3,2) * \mathrm{COV} 19(-2)+\mathrm{C}(3,3) * \mathrm{CPI}(-1)+$ $\mathrm{C}(3,4) * \mathrm{CPI}(-2)+\mathrm{C}(3,5) * \mathrm{EMP}(-1)+\mathrm{C}(3,6) * \mathrm{EMP}(-2)+\mathrm{C}(3,7) * \mathrm{EX}(-1)+$ $\mathrm{C}(3,8) * \operatorname{EX}(-2)+\mathrm{C}(3,9) * \operatorname{GOVEXP}(-1)+\mathrm{C}(3,10) * \operatorname{GOVEXP}(-2)+$ $\mathrm{C}(3,11) * \operatorname{IM}(-1)+\mathrm{C}(3,12) * \operatorname{IM}(-2)+\mathrm{C}(3,13) * \operatorname{INV}(-1)+\mathrm{C}(3,14) * \operatorname{INV}(-2)+$ $\mathrm{C}(3,15)$ 
$\mathrm{EX}=\mathrm{C}(4,1) * \mathrm{COV} 19(-1)+\mathrm{C}(4,2) * \mathrm{COV} 19(-2)+\mathrm{C}(4,3) * \mathrm{CPI}(-1)+$ $\mathrm{C}(4,4) * \mathrm{CPI}(-2)+\mathrm{C}(4,5) * \mathrm{EMP}(-1)+\mathrm{C}(4,6) * \mathrm{EMP}(-2)+\mathrm{C}(4,7) * \mathrm{EX}(-1)+$ $\mathrm{C}(4,8) * \operatorname{EX}(-2)+\mathrm{C}(4,9) * \operatorname{GOVEXP}(-1)+\mathrm{C}(4,10) * \operatorname{GOVEXP}(-2)+$ $\mathrm{C}(4,11) * \mathrm{IM}(-1)+\mathrm{C}(4,12) * \operatorname{IM}(-2)+\mathrm{C}(4,13) * \operatorname{INV}(-1)+\mathrm{C}(4,14) * \operatorname{INV}(-2)+$ $\mathrm{C}(4,15)$

GOVEXP $=\mathrm{C}(5,1) * \operatorname{COV} 19(-1)+\mathrm{C}(5,2) * \operatorname{COV} 19(-2)+\mathrm{C}(5,3) * \mathrm{CPI}(-1)+$ $\mathrm{C}(5,4) * \mathrm{CPI}(-2)+\mathrm{C}(5,5) * \mathrm{EMP}(-1)+\mathrm{C}(5,6) * \mathrm{EMP}(-2)+\mathrm{C}(5,7) * \mathrm{EX}(-1)+$ $\mathrm{C}(5,8) * \mathrm{EX}(-2)+\mathrm{C}(5,9) * \mathrm{GOVEXP}(-1)+\mathrm{C}(5,10) * \operatorname{GOVEXP}(-2)+$ $\mathrm{C}(5,11) * \mathrm{IM}(-1)+\mathrm{C}(5,12) * \operatorname{IM}(-2)+\mathrm{C}(5,13) * \operatorname{INV}(-1)+\mathrm{C}(5,14) * \operatorname{INV}(-2)+$ $\mathrm{C}(5,15)$

$\mathrm{IM}=\mathrm{C}(6,1) * \mathrm{COV} 19(-1)+\mathrm{C}(6,2) * \mathrm{COV} 19(-2)+\mathrm{C}(6,3) * \mathrm{CPI}(-1)+$ $\mathrm{C}(6,4) * \mathrm{CPI}(-2)+\mathrm{C}(6,5) * \mathrm{EMP}(-1)+\mathrm{C}(6,6) * \mathrm{EMP}(-2)+\mathrm{C}(6,7) * \mathrm{EX}(-1)+$ $\mathrm{C}(6,8) * \mathrm{EX}(-2)+\mathrm{C}(6,9) * \mathrm{GOVEXP}(-1)+\mathrm{C}(6,10) * \operatorname{GOVEXP}(-2)+$ $\mathrm{C}(6,11) * \mathrm{IM}(-1)+\mathrm{C}(6,12) * \operatorname{IM}(-2)+\mathrm{C}(6,13) * \operatorname{INV}(-1)+\mathrm{C}(6,14) * \operatorname{INV}(-2)+$ $\mathrm{C}(6,15)$

$\mathrm{INV}=\mathrm{C}(7,1) * \mathrm{COV} 19(-1)+\mathrm{C}(7,2) * \mathrm{COV} 19(-2)+\mathrm{C}(7,3) * \mathrm{CPI}(-1)+$ $\mathrm{C}(7,4) * \mathrm{CPI}(-2)+\mathrm{C}(7,5) * \mathrm{EMP}(-1)+\mathrm{C}(7,6) * \mathrm{EMP}(-2)+\mathrm{C}(7,7) * \mathrm{EX}(-1)+$ $\mathrm{C}(7,8) * \mathrm{EX}(-2)+\mathrm{C}(7,9) * \operatorname{GOVEXP}(-1)+\mathrm{C}(7,10) * \operatorname{GOVEXP}(-2)+$ $\mathrm{C}(7,11) * \mathrm{IM}(-1)+\mathrm{C}(7,12) * \operatorname{IM}(-2)+\mathrm{C}(7,13) * \operatorname{INV}(-1)+\mathrm{C}(7,14) * \operatorname{INV}(-2)+$ $\mathrm{C}(7,15)$

Where,

COV19: World Pandemic Uncertainty Index (WPUI)

CPI: Consumer Price Index

EMP: Number of Employment

EX: Value of Exports, by Major Commodity Groups

GOVEXP: Government Expenditure

IM: Import Value of Imports, by Major Commodity Groups

INV: Investment Capital of Domestic and Foreign

The weekly sample data covered the Arab countries during 2020 from 1/1/2020 to 31/1/2020. The Value of Exports by Major Commodity Groups and the Value of Imports by Major Commodity Groups were collected from the World Trade Organization (WTO), Statistics on Merchandise Trade Database 2020, https://data.wto.org/. The rest variables were collected from the World Bank database 2021, http://www.worldbankdatabase.org.

The Unit Root Test

A unit root test was performed using the augmented Dickey-Fuller (ADF) method to examine the stability of the time series, as the first step to analyze the data and examine the properties of the time series to avoid the false 
regression problem. The null hypothesis was: the time series has a unit root problem (the time series is not static), and the alternative hypothesis was: the time series does not have a unit root problem (the time series is static).

Table (4): Results of the Augmented Dickey-Fuller Test (ADF)

\begin{tabular}{|c|c|c|c|c|c|c|c|c|}
\hline \multicolumn{2}{|l|}{ At Level } & COV19 & CPI & EMP & EX & $\begin{array}{l}\text { GOVEX } \\
\mathrm{P}\end{array}$ & IM & INV \\
\hline $\begin{array}{l}\text { With } \\
\text { Constant }\end{array}$ & $\begin{array}{l}\text { t- } \\
\text { Statisti } \\
\mathrm{c}\end{array}$ & -1.6874 & -1.0175 & -1.6257 & -1.8998 & -1.2149 & -0.6688 & -0.8616 \\
\hline & Prob. & 0.4316 & 0.7405 & 0.4625 & 0.3299 & 0.6614 & 0.8453 & 0.7926 \\
\hline \begin{tabular}{|l} 
With \\
Constant \\
Trend
\end{tabular} & $\&{ }_{c}^{\mathrm{t}-}$ & -1.6194 & -1.9619 & -1.4387 & -1.7693 & -1.3575 & -1.6304 & -1.5280 \\
\hline & Prob. & 0.7717 & 0.6079 & 0.8375 & 0.7052 & 0.8618 & 0.7672 & 0.8070 \\
\hline $\begin{array}{l}\text { Without } \\
\text { Constant } \\
\text { Trend }\end{array}$ & $\&$ Statisti $_{\mathrm{c}}^{\mathrm{t}-}$ & 0.7726 & 0.9572 & -0.2203 & -0.3610 & 0.2287 & 0.6628 & 0.4811 \\
\hline & Prob. & 0.8774 & 0.9080 & 0.6021 & 0.5499 & 0.5991 & 0.8561 & 0.8156 \\
\hline At First I & ifference & $\begin{array}{l}\mathrm{d}(\mathrm{COV} \\
19)\end{array}$ & d(CPI) & $\mathrm{d}(\mathrm{EMP})$ & $\mathrm{d}(\mathrm{EX})$ & $\begin{array}{l}\text { d(GOVE } \\
\text { XP) }\end{array}$ & $\mathrm{d}(\mathrm{IM})$ & $\mathrm{d}(\mathrm{INV})$ \\
\hline $\begin{array}{l}\text { With } \\
\text { Constant }\end{array}$ & $\begin{array}{l}\text { t- } \\
\text { Statisti } \\
\mathrm{c}\end{array}$ & -7.1806 & -7.1311 & -7.0052 & -7.0163 & -7.0072 & -7.0624 & -7.0330 \\
\hline & Prob. & 0.0000 & 0.0000 & 0.0000 & 0.0000 & 0.0000 & 0.0000 & 0.0000 \\
\hline $\begin{array}{l}\text { With } \\
\text { Constant } \\
\text { Trend }\end{array}$ & $\left.\&\right|_{c} ^{t-}$ & -7.2382 & -7.0583 & -7.1589 & -7.0342 & -7.1413 & -7.1882 & -7.1763 \\
\hline & Prob. & 0.0000 & 0.0000 & 0.0000 & 0.0000 & 0.0000 & 0.0000 & 0.0000 \\
\hline $\begin{array}{l}\text { Without } \\
\text { Constant } \\
\text { Trend }\end{array}$ & $\begin{array}{l}\mathrm{t}- \\
\text { Statisti } \\
\mathrm{c}\end{array}$ & $\mathrm{i} \mid-7.0711$ & -7.0711 & -7.0711 & -7.0711 & -7.0711 & -7.0711 & -7.0711 \\
\hline & Prob. & 0.0000 & 0.0000 & 0.0000 & 0.0000 & 0.0000 & 0.0000 & 0.0000 \\
\hline
\end{tabular}

Source: Author using Eviews 10.

Table 4 showed the augmented Dickey-Fuller (ADF) test results that time series for all variables aren't static. And after taking the first differences, the time series of all variables for the first differences are static with a confidence degree of $99 \%$, so all variables are being stationary at the first differences.

Table (5): Results of the PVAR Model 
مجلة كلية السياسة والاقتصاد العدد الثاني عشر - أكتوبر I.Y

\begin{tabular}{|c|c|c|c|c|c|c|c|}
\hline & COV19 & CPI & EMP & EX & GOVEXP & IM & INV \\
\hline \multirow{2}{*}{ OV19(-1) } & 0.404973 & 0.002300 & -0.001507 & -0.016210 & 0.000238 & 0.002532 & 0.001598 \\
\hline & $(0.07496)$ & $(0.00087)$ & $(0.00068)$ & $(0.00578)$ & $(0.00212)$ & $(0.00219)$ & $(0.00319$ \\
\hline \multirow[t]{2}{*}{ OV19(-2) } & 0.082472 & 0.000667 & -0.000232 & -0.002463 & $-7.96 \mathrm{E}-05$ & 0.000855 & 0.000755 \\
\hline & $(0.04567)$ & $(0.00053)$ & $(0.00041)$ & $(0.00351)$ & $(0.00129)$ & $(0.00133)$ & $(0.00194$ \\
\hline \multirow[t]{2}{*}{$\mathrm{PI}(-1)$} & 14.86609 & 0.523094 & 0.014037 & 1.140531 & 0.192362 & 0.344822 & 0.300272 \\
\hline & $(0.06710)$ & $(0.06644)$ & $(0.05161)$ & $(0.04393)$ & $(0.01615)$ & $(0.01667)$ & $(0.02429$ \\
\hline \multirow[t]{2}{*}{$\mathrm{PI}(-2)$} & 3.507709 & 0.107179 & 0.005543 & 0.207551 & 0.014415 & 0.097382 & 0.097942 \\
\hline & $(0.08169)$ & $(0.04490)$ & $(0.03476)$ & $(0.02957)$ & $(0.01087)$ & $(0.01123)$ & $(0.01636$ \\
\hline \multirow[t]{2}{*}{$\mathrm{MP}(-1)$} & -19.47333 & -0.016602 & 0.177213 & 1.245583 & -0.388428 & 0.369175 & 0.598343 \\
\hline & $(0.07528)$ & $(0.01395)$ & $(0.08973)$ & $(0.05732)$ & $(0.07857)$ & $(0.02760)$ & $(0.04189$ \\
\hline \multirow[t]{2}{*}{$\mathrm{MP}(-2)$} & -3.558638 & -0.019233 & 0.026950 & 0.159995 & -0.064406 & 0.043853 & 0.080153 \\
\hline & $(0.16877)$ & $(0.06027)$ & $(0.04751)$ & $(0.00048)$ & $(0.04733)$ & $(0.05211)$ & $(0.02158$ \\
\hline \multirow[t]{2}{*}{$\mathrm{X}(-1)$} & -2.891310 & 0.022426 & 0.018232 & 0.284792 & 0.011244 & 0.008570 & 0.016209 \\
\hline & $(0.05866)$ & $(0.01234)$ & $(0.0$ & $(0.08253)$ & 0.0 & $(0.1$ & $(0$ \\
\hline \multirow[t]{2}{*}{$X(-2)$} & -0.541932 & 0.002449 & 0.003106 & 0.046129 & 508 & 432 & 841 \\
\hline & $(0.09727)$ & $(0.00696)$ & $(0.00544)$ & $(0.04668)$ & $(0.01702)$ & $(0.01757)$ & 2560 \\
\hline \multirow[t]{2}{*}{ SOVEXP(-1) } & 0.580070 & 0.043204 & -0.038378 & 0.110982 & 0.235465 & -0.1 & -0.292747 \\
\hline & $(0.09280)$ & $(0.03491)$ & $(0.02727)$ & $(0.03190)$ & $(0.08596)$ & $(0.08814)$ & $(0.02840$ \\
\hline \multirow[t]{2}{*}{ OVEXP(-2) } & 0.010606 & 0.010774 & -0.005042 & 0.038921 & 0.039133 & -0.028895 & -0.0 \\
\hline & $(0.03700)$ & $(0.01909)$ & $(0.1$ & 884) & $(0$. & $(0$. & $(0$ \\
\hline \multirow[t]{2}{*}{$\mathrm{M}(-1)$} & 2.292231 & 0.043077 & 162 & 491 & 037 & 823 & 502 \\
\hline & \begin{tabular}{|l|}
$(0.08719)$ \\
\end{tabular} & $(0.03368)$ & $(0.02630)$ & $(0.02369)$ & $(0.08235)$ & $(0.08560)$ & $(0.12388$ \\
\hline \multirow[t]{2}{*}{$\mathrm{M}(-2)$} & 0.649831 & 0.007168 & 0.005571 & -0.007522 & -0.035387 & 0.045976 & 0.059997 \\
\hline & $(0.05618)$ & $(0.01850)$ & $(0.01445)$ & $(0.02290)$ & $(0.04522)$ & $(0.04710)$ & $(0.06801)$ \\
\hline \multirow[t]{2}{*}{$\mathrm{NV}(-1)$} & 0.491588 & 0.014343 & 0.028167 & 0.045820 & -0.135101 & 0.156533 & 0.221800 \\
\hline & $(0.02399)$ & $(0.02361)$ & $(0.0$ & 583) & 773) & $(0.0$ & 8745 \\
\hline \multirow[t]{4}{*}{$N V(-2)$} & 0.213315 & 0.001456 & 0.004065 & -0.004523 & -0.023873 & 0.026671 & 0.037616 \\
\hline & $(0.09362)$ & $(0.01275)$ & $(0.00996)$ & $(0.08474)$ & $(0.03118)$ & $(0.03219)$ & $(0.04731$ \\
\hline & -80.11937 & -0.705041 & 0.451842 & -5.062416 & 22.57040 & 7.136359 & 14.58100 \\
\hline & $(103.040)$ & $(1.20172)$ & $(0.93860)$ & $(7.98369)$ & $(2.95628)$ & (3.03484) & $(4.42424$ \\
\hline -squared & 0.901328 & 0.914629 & 0.853377 & 0.878386 & 0.852502 & 0.888927 & 0.873456 \\
\hline dj. R-squared & 0.862956 & 0.881430 & 0.782468 & 0.692203 & 0.781253 & 0.845732 & 0.824245 \\
\hline um sq. resids & 23.57936 & 0.003207 & 0.001809 & 0.143616 & 0.017982 & 0.018538 & 0.039244 \\
\hline .E. equation & 0.809310 & 0.009439 & 0.007088 & 0.063161 & 0.022350 & 0.022692 & 0.033017 \\
\hline -statistic & 23.48894 & 27.54938 & 13.84654 & 9.031773 & 13.75535 & 20.57938 & 17.74906 \\
\hline Mean dependent & 11.43693 & 4.619304 & 0.862071 & 10.66549 & 24.94396 & 10.40778 & 17.49439 \\
\hline .D. dependent & 2.186171 & 0.027411 & 0.015197 & 0.113846 & 0.047786 & 0.057775 & 0.078756 \\
\hline \multicolumn{8}{|c|}{$\begin{array}{l}\text { Source: Author using Eviews } 10 \text {. } \\
\text { Results indicated that the explanatory level of the model, R-squared, for } \\
\text { all equations greater than } 0.85 \text { which means that the independent variables can }\end{array}$} \\
\hline
\end{tabular}


explain more than $85 \%$ of variation in the dependent variable in the seven equations, and the rest were due to other factors, including random errors. Also, the overall significance of the model, F-statistic, was significant for all equations, which means that the estimated model is significant (accepting alternative hypothesis). This indicated that the independent variables have a significant effect on the dependent variable in the seven equations. Moreover, results indicated partial significance of the model where parameters were statistically significant. These parameters differed substantially from zero and as a result the importance of the independent variables was reflected (table 5).

The Substituted Coefficients are as follows:

COV19 $=0.404972731888 * \operatorname{COV} 19(-1)+0.0824722614938 * \operatorname{COV} 19(-2)+$ $14.8660865148 * \mathrm{CPI}(-1)+3.50770909398 * \mathrm{CPI}(-2)-19.4733303562 * \mathrm{EMP}(-1)$ - 3.5586381283*EMP(-2) - 2.89130992275*EX(-1) - 0.541932251716*EX(-2) $+\quad 0.58006975468 * \operatorname{GOVEXP}(-1)+0.0106059889222 * \operatorname{GOVEXP}(-2)+$ $2.29223130463 * \operatorname{IM}(-1)+0.649831413524 * \operatorname{IM}(-2)+0.491588244593 * \operatorname{INV}(-1)$ $+0.213315153247 * \operatorname{INV}(-2)-80.1193729714$

$\mathrm{CPI}=0.00229975280799 * \operatorname{COV} 19(-1)+0.000667325451275 * \operatorname{COV} 19(-2)+$ $0.523093977972 * \mathrm{CPI}(-1)+0.107179000575 * \mathrm{CPI}(-2)$

$0.0166021631521 * \mathrm{EMP}(-1) \quad-\quad 0.0192325617572 * \mathrm{EMP}(-2)$

$0.0224259121633 * \mathrm{EX}(-1)+0.00244944094129 * \mathrm{EX}(-2)$

$0.0432035742124 * \operatorname{GOVEXP}(-1)+0.0107744476991 * \operatorname{GOVEXP}(-2)+$

$0.0430772032414 * \operatorname{IM}(-1)+0.00716832335456 * \operatorname{IM}(-2)+$

$0.0143432792829 * \operatorname{INV}(-1)+0.00145616846021 * \operatorname{INV}(-2)-0.705040906556$

$\mathrm{EMP}=-0.00150736674682 * \operatorname{COV} 19(-1)-0.000231919436434 * \operatorname{COV} 19(-2)+$ $0.0140373974227 * \mathrm{CPI}(-1)+0.00554278090635^{*} \mathrm{CPI}(-2)+$

$0.177212937493 * \operatorname{EMP}(-1)+0.0269497904601 * \operatorname{EMP}(-2)+$

$0.0182323972979 * \operatorname{EX}(-1)+0.00310597450621 * \mathrm{EX}(-2) \quad-$

$0.0383777414681 * \operatorname{GOVEXP}(-1) \quad-\quad 0.00504156826719 * \operatorname{GOVEXP}(-2) \quad+$

$0.0381623073226 * \mathrm{IM}(-1)+0.00557117858943 * \mathrm{IM}(-2)+$ $0.0281668056523 * \operatorname{INV}(-1)+0.00406484830501 * \operatorname{INV}(-2)+0.451841641683$ $\mathrm{EX}=-0.0162101331622 * \operatorname{COV} 19(-1)-0.00246271227684 * \operatorname{COV} 19(-2)+$ $1.14053116855 * \mathrm{CPI}(-1)+0.207551402746 * \mathrm{CPI}(-2)+1.24558253729 * \mathrm{EMP}(-$

$1)+0.159994678834 * \mathrm{EMP}(-2)+0.284791895034 * \mathrm{EX}(-1)+$ $0.0461293597432 * \operatorname{EX}(-2)+0.110981707694 * \operatorname{GOVEXP}(-1)+$

$0.038921385305 * \operatorname{GOVEXP}(-2)+0.0564913520648 * \operatorname{IM}(-1)$ $0.0075221116349 * \operatorname{IM}(-2)+0.0458201943547 * \operatorname{INV}(-1)$

$0.00452342979406 * \operatorname{INV}(-2)-5.0624164138$

GOVEXP $=0.000237584975082 *$ COV19(-1) $-7.95895156216 \mathrm{e}-05 *$ COV19($2)+0.192361634923 * \mathrm{CPI}(-1)+0.0144151653003 * \mathrm{CPI}(-2) \quad-$

$0.388427889382 * \operatorname{EMP}(-1)$

$0.0644062077481 * \mathrm{EMP}(-2)$

$0.0112439456316 * \mathrm{EX}(-1)$

$+\quad 0.00150796373282 * \mathrm{EX}(-2)$ 
$0.235465166043 * \operatorname{GOVEXP}(-1)+0.0391333095613 * \operatorname{GOVEXP}(-2) \quad-$

$0.195036505524 * \mathrm{IM}(-1)-0.0353871011175 * \mathrm{IM}(-2)-0.135101279389 * \mathrm{INV}(-$

1) $-0.0238728901531 * \operatorname{INV}(-2)+22.5704034269$

$\mathrm{IM}=0.00253183982672 * \operatorname{COV} 19(-1)+0.000855173123171 * \operatorname{COV} 19(-2)+$ $0.344821960374 * \mathrm{CPI}(-1)+0.0973824244247 * \mathrm{CPI}(-2)+$

$0.369174581705 * \operatorname{EMP}(-1)+0.0438533176493 * \operatorname{EMP}(-2)+$

$0.00856973726513 * \operatorname{EX}(-1)+0.000431924402619 * \operatorname{EX}(-2) \quad-$

$0.195850742777 *$ GOVEXP(-1) - $0.0288954247371 *$ GOVEXP $(-2)+$

$0.255822742067 * \operatorname{IM}(-1)+0.0459764239677 * \operatorname{IM}(-2)+$

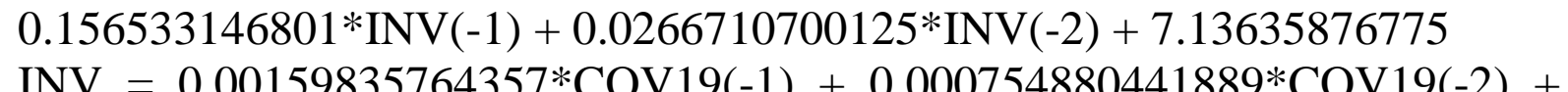

$\mathrm{INV}=0.00159835764357 * \operatorname{COV} 19(-1)+0.000754880441889 * \operatorname{COV} 19(-2)+$

$0.300271718123 * \mathrm{CPI}(-1)+0.0979418438619 * \mathrm{CPI}(-2)+$

$0.598343175661 * \operatorname{EMP}(-1)+0.0801527442163 * \operatorname{EMP}(-2)+$

$0.0162089857513 * \mathrm{EX}(-1)+0.00184077061795 * \mathrm{EX}(-2) \quad-$

$0.292747388303 *$ GOVEXP(-1) - $0.0441480070149 *$ GOVEXP(-2) $\quad+$

$0.337501609669 * \mathrm{IM}(-1)+0.0599968567622 * \mathrm{IM}(-2) \quad+$

$0.221799614577 * \operatorname{INV}(-1)+0.0376160926389 * \operatorname{INV}(-2)+14.5810033418$

Table (6): Variance Decomposition

\begin{tabular}{|c|c|c|c|c|c|c|c|c|c|}
\hline & $\begin{array}{l}\text { Perio } \\
\mathrm{d}\end{array}$ & S.E. & PI & COV19 & MP & EX & $\begin{array}{l}\text { GOVI } \\
\mathrm{P}\end{array}$ & IM & $\mathrm{NV}$ \\
\hline \multirow{11}{*}{ 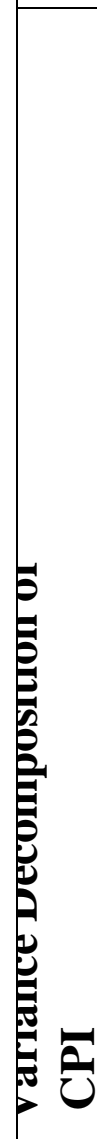 } & & & & & & 0.0000 & 0.00000 & & \\
\hline & 1 & 08174 & 100.0000 & & 0.000000 & 00 & 0 & 0.000000 & 0.000000 \\
\hline & 2 & & 9 & $\begin{array}{l}0.25633 \\
7\end{array}$ & 0.16 & $\begin{array}{l}3.93 \mathrm{E}- \\
06\end{array}$ & $\begin{array}{l}5.35 \mathrm{E}- \\
07\end{array}$ & 08 & 1 \\
\hline & 3 & 0. & 98.2 & $5^{1.25237}$ & 0.291305 & $\begin{array}{l}4.15 \mathrm{E}- \\
06\end{array}$ & $\begin{array}{l}9.81 \mathrm{E}- \\
07\end{array}$ & $1.09 \mathrm{E}-07$ & $1.87 \mathrm{E}-09$ \\
\hline & 4 & 0 & 96.9 & $\begin{array}{l}2.57615 \\
9\end{array}$ & 0.426387 & $\begin{array}{l}3.73 \mathrm{E}- \\
06\end{array}$ & $\begin{array}{l}1.39 \mathrm{E}- \\
06\end{array}$ & -07 & 2.4 \\
\hline & 5 & & 95.3 & $\begin{array}{l}4.10641 \\
5\end{array}$ & 0.5 & $\begin{array}{l}3.39 \mathrm{E}- \\
06\end{array}$ & $\begin{array}{l}1.74 \mathrm{E}- \\
06\end{array}$ & -07 & 2.8 \\
\hline & 6 & 19 & 93.6 & $\begin{array}{l}5.68716 \\
2\end{array}$ & 0.63 & $\begin{array}{l}3.23 \mathrm{E}- \\
06\end{array}$ & $\begin{array}{l}2.03 \mathrm{E}- \\
06\end{array}$ & -07 & 3.2 \\
\hline & 7 & & 92.07303 & $\begin{array}{l}7.22661 \\
7\end{array}$ & 0.700344 & $\begin{array}{l}3.21 \mathrm{E}- \\
06\end{array}$ & $\begin{array}{l}2.26 \mathrm{E}- \\
06\end{array}$ & $1.91 \mathrm{E}-07$ & 3.47E-09 \\
\hline & 8 & & 90.5 & $\begin{array}{l}8.66794 \\
9\end{array}$ & & $\begin{array}{l}3.28 \mathrm{E}- \\
06\end{array}$ & $\begin{array}{l}2.45 \mathrm{E}- \\
06\end{array}$ & 2.01E-07 & $3.65 \mathrm{E}-09$ \\
\hline & 9 & 013728 & 89.24206 & $\begin{array}{l}9.98210 \\
3\end{array}$ & 0.77 & $\begin{array}{l}3.40 \mathrm{E}- \\
06\end{array}$ & $\begin{array}{l}2.58 \mathrm{E}- \\
06\end{array}$ & $2.08 \mathrm{E}-07$ & $3.78 \mathrm{E}-09$ \\
\hline & 1 & 0.013930 & 88.04985 & $3^{11.1580}$ & 0.792111 & $\begin{array}{l}3.54 \mathrm{E} \\
06\end{array}$ & $\begin{array}{l}2.68 \mathrm{E}- \\
06\end{array}$ & 2.13E-07 & $3.87 \mathrm{E}-09$ \\
\hline
\end{tabular}




\begin{tabular}{|c|c|c|c|c|c|c|c|c|c|}
\hline & 11 & 8 & 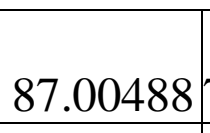 & \begin{tabular}{|l}
12.1959 \\
7
\end{tabular} & 799140 & $\begin{array}{l}3.67 \mathrm{E}- \\
06\end{array}$ & $\begin{array}{l}2.75 \mathrm{E}- \\
06\end{array}$ & 07 & 3 \\
\hline & 12 & 14238 & 86.09730 & $\begin{array}{l}13.1027 \\
5\end{array}$ & 0.799943 & $\begin{array}{l}3.79 \mathrm{E}- \\
06\end{array}$ & $\begin{array}{l}2.80 \mathrm{E}- \\
06\end{array}$ & $18 \mathrm{E}-07$ & 3.97E-09 \\
\hline & 1 & 383 & 05 & $\begin{array}{l}99.3006 \\
9\end{array}$ & 000 & $\begin{array}{l}0.0000 \\
00\end{array}$ & $\begin{array}{l}0.00000 \\
0\end{array}$ & 000 & 0.000000 \\
\hline & 2 & 77 & 0.90 & $\begin{array}{l}98.9745 \\
6\end{array}$ & 121765 & $\begin{array}{l}8.45 \mathrm{E}- \\
06\end{array}$ & $\begin{array}{l}3.52 \mathrm{E}- \\
07\end{array}$ & -08 & $1.74 \mathrm{E}-10$ \\
\hline & 3 & 06 & 41 & $\begin{array}{l}98.5839 \\
9\end{array}$ & & $\begin{array}{l}1.10 \mathrm{E}- \\
05\end{array}$ & $\begin{array}{l}4.22 \mathrm{E}- \\
07\end{array}$ & -08 & -10 \\
\hline & 4 & 27 & 760 & $\begin{array}{l}98.2002 \\
6 \\
\end{array}$ & & $\begin{array}{l}1.15 \mathrm{E}- \\
05\end{array}$ & $\begin{array}{l}4.03 \mathrm{E}- \\
07\end{array}$ & -08 & E-10 \\
\hline & 5 & 970 & 99 & $\begin{array}{l}97.8439 \\
2\end{array}$ & 71 & $\begin{array}{l}1.14 \mathrm{E}- \\
05\end{array}$ & $\begin{array}{l}3.71 \mathrm{E}- \\
07\end{array}$ & $E-08$ & $1.62 \mathrm{E}-10$ \\
\hline 2 & 6 & 311 & 1.713037 & $\begin{array}{l}97.5254 \\
4\end{array}$ & 0.76 & $\begin{array}{l}1.11 \mathrm{E}- \\
05\end{array}$ & $\begin{array}{l}3.44 \mathrm{E}- \\
07\end{array}$ & E-08 & $1.53 \mathrm{E}-10$ \\
\hline 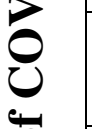 & 7 & & 820273 & $\begin{array}{l}97.2472 \\
1\end{array}$ & & $\begin{array}{l}1.08 \mathrm{E}- \\
05\end{array}$ & $\begin{array}{l}3.27 \mathrm{E}- \\
07\end{array}$ & -08 & $\mathrm{E}-10$ \\
\hline है & 8 & & 19 & $\begin{array}{l}97.0076 \\
8\end{array}$ & & $\begin{array}{l}1.05 \mathrm{E}- \\
05\end{array}$ & $\begin{array}{l}3.20 \mathrm{E}- \\
07\end{array}$ & -08 & -10 \\
\hline है: & 9 & 48 & 17 & $\begin{array}{l}96.8033 \\
2\end{array}$ & 56 & $\begin{array}{l}1.02 \mathrm{E}- \\
05\end{array}$ & $\begin{array}{l}3.20 \mathrm{E}- \\
07\end{array}$ & -08 & $.81 \mathrm{E}-10$ \\
\hline 递 & 10 & & 06 & $\begin{array}{l}96.6298 \\
3\end{array}$ & & $\begin{array}{l}9.99 \mathrm{E}- \\
06\end{array}$ & $\begin{array}{l}3.27 \mathrm{E}- \\
07\end{array}$ & -08 & $8-10$ \\
\hline$\underset{\Xi}{\Xi}$ & 11 & & 2 & $\begin{array}{l}96.4828 \\
9\end{array}$ & & $\begin{array}{l}9.82 \mathrm{E}- \\
06\end{array}$ & $\begin{array}{l}3.39 \mathrm{E}- \\
07\end{array}$ & -08 & $\mathrm{z}-10$ \\
\hline 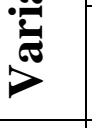 & 12 & 38 & 2.01 & $\begin{array}{l}96.3584 \\
5\end{array}$ & 0 & $\begin{array}{l}9.68 \mathrm{E}- \\
06\end{array}$ & $\begin{array}{l}3.54 \mathrm{E}- \\
07\end{array}$ & -08 & 2.5 \\
\hline 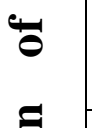 & 1 & & & \begin{tabular}{|l|}
66.5068 \\
7 \\
\end{tabular} & 3 & $\begin{array}{l}0.0000 \\
00\end{array}$ & $\begin{array}{l}0.00000 \\
0\end{array}$ & 000 & 000 \\
\hline 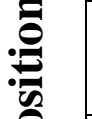 & 2 & 86 & 2 & $\begin{array}{l}65.0764 \\
2\end{array}$ & & $\begin{array}{l}3.58 \mathrm{E}- \\
06\end{array}$ & $\begin{array}{l}5.88 \mathrm{E}- \\
06\end{array}$ & -07 & E-09 \\
\hline है: & 3 & & 2.28 & $\begin{array}{l}63.8198 \\
3\end{array}$ & & $\begin{array}{l}5.32 \mathrm{E}- \\
06\end{array}$ & $\begin{array}{l}8.63 \mathrm{E}- \\
06\end{array}$ & -07 & $1.05 \mathrm{E}-08$ \\
\hline ڤ્u & 4 & 06 & & \begin{tabular}{|l|}
62.6345 \\
3 \\
\end{tabular} & 5 & $\begin{array}{l}6.49 \mathrm{E}- \\
06\end{array}$ & $\begin{array}{l}1.03 \mathrm{E}- \\
05\end{array}$ & -07 & -08 \\
\hline 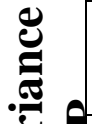 & 5 & 10055 & 09588 & \begin{tabular}{|l|}
61.5257 \\
8 \\
\end{tabular} & $55.3 / 052$ & $\begin{array}{l}7.39 \mathrm{E}- \\
06\end{array}$ & $\begin{array}{l}1.15 \mathrm{E}- \\
05\end{array}$ & $3.50 \mathrm{E}-07$ & $1.39 \mathrm{E}-08$ \\
\hline 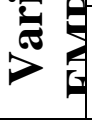 & & 010464 & 3.50 & $\begin{array}{l}60.4956 \\
5\end{array}$ & $3 J$ & $\begin{array}{l}8.14 \mathrm{E}- \\
06\end{array}$ & $\begin{array}{l}1.24 \mathrm{E}- \\
05\end{array}$ & $3.81 \mathrm{E}-07$ & 1.51E-08 \\
\hline
\end{tabular}




\begin{tabular}{|c|c|c|c|c|c|c|c|c|c|}
\hline & 7 & & & $\begin{array}{l}59.5472 \\
7\end{array}$ & & $\begin{array}{l}8.78 \mathrm{E}- \\
06\end{array}$ & $\begin{array}{l}1.32 \mathrm{E}- \\
05\end{array}$ & & \\
\hline & 8 & & & $\begin{array}{l}58.6822 \\
9\end{array}$ & 791 & $\begin{array}{l}9.33 \mathrm{E}- \\
06\end{array}$ & $\begin{array}{l}1.38 \mathrm{E}- \\
05\end{array}$ & -07 & -00 \\
\hline & 9 & 196 & 802 & $\begin{array}{l}57.9007 \\
2\end{array}$ & 37.41137 & $\begin{array}{l}9.82 \mathrm{E}- \\
06\end{array}$ & $\begin{array}{l}1.43 \mathrm{E}- \\
05\end{array}$ & $4.47 \mathrm{E}-07$ & $1.73 \mathrm{E}-0$ \\
\hline & 10 & 39 & 5.0455905 & $\begin{array}{l}57.2009 \\
5\end{array}$ & 37.75344 & $\begin{array}{l}1.03 \mathrm{E}- \\
05\end{array}$ & $\begin{array}{l}1.48 \mathrm{E}- \\
05\end{array}$ & 4.63E-07 & $1.78 \mathrm{E}-08$ \\
\hline & 11 & 51 & 5.38 & $\begin{array}{l}56.5799 \\
4\end{array}$ & 38.0 & $\begin{array}{l}1.06 \mathrm{E}- \\
05\end{array}$ & $\begin{array}{l}1.51 \mathrm{E}- \\
05\end{array}$ & $4.77 \mathrm{E}-07$ & $1.82 \mathrm{E}-08$ \\
\hline & 12 & & 5.69 & $\begin{array}{l}56.0335 \\
1\end{array}$ & & $\begin{array}{l}1.10 \mathrm{E}- \\
05\end{array}$ & $\begin{array}{l}1.54 \mathrm{E}- \\
05\end{array}$ & -07 & -08 \\
\hline & 1 & 699 & 28.780034 & $\begin{array}{l}71.0411 \\
4\end{array}$ & & $\begin{array}{l}0.0001 \\
85\end{array}$ & $\begin{array}{l}0.00000 \\
0\end{array}$ & 000 & 0.00000 \\
\hline & 2 & 581 & 27.9 & $\begin{array}{l}71.3031 \\
4 \\
\end{array}$ & 0.764490 & $\begin{array}{l}0.0001 \\
40\end{array}$ & $\begin{array}{l}2.22 \mathrm{E}- \\
08\end{array}$ & $.78 \mathrm{E}-09$ & $2.59 \mathrm{E}-10$ \\
\hline & 3 & 192 & 677 & $\begin{array}{l}71.1456 \\
7\end{array}$ & 32 & $\begin{array}{l}0.0001 \\
21\end{array}$ & $\begin{array}{l}1.06 \mathrm{E}- \\
07\end{array}$ & -08 & $5.35 \mathrm{E}-10$ \\
\hline & 4 & 50 & 27.329104 & $\begin{array}{l}70.8184 \\
4\end{array}$ & 54 & $\begin{array}{l}0.0001 \\
10\end{array}$ & $\begin{array}{l}2.74 \mathrm{E}- \\
07\end{array}$ & -08 & $8.73 \mathrm{E}-10$ \\
\hline & 5 & & 27.1 & $\begin{array}{l}70.4023 \\
0\end{array}$ & & $\begin{array}{l}0.0001 \\
04\end{array}$ & $\begin{array}{l}4.89 \mathrm{E}- \\
07\end{array}$ & -08 & -09 \\
\hline & 6 & 441 & 27.1 & $\begin{array}{l}69.9495 \\
5\end{array}$ & 06 & $\begin{array}{l}9.96 \mathrm{E}- \\
05\end{array}$ & $\begin{array}{l}7.30 \mathrm{E}- \\
07\end{array}$ & -08 & $1.59 \mathrm{E}-09$ \\
\hline & 7 & 640 & 671 & $\begin{array}{l}69.4951 \\
1\end{array}$ & 20 & $\begin{array}{l}9.67 \mathrm{E}- \\
05\end{array}$ & $\begin{array}{l}9.76 \mathrm{E}- \\
07\end{array}$ & 07E-08 & $1.93 \mathrm{E}-09$ \\
\hline 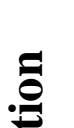 & 8 & 195 & 27.0 & $\begin{array}{l}69.0608 \\
2\end{array}$ & & $\begin{array}{l}9.47 \mathrm{E}- \\
05\end{array}$ & $\begin{array}{l}1.22 \mathrm{E}- \\
06\end{array}$ & -08 & $2.25 \mathrm{E}-09$ \\
\hline 它 & 9 & 18 & 27.0 & $\begin{array}{l}68.6593 \\
4 \\
\end{array}$ & 4. & $\begin{array}{l}9.33 \mathrm{E}- \\
05\end{array}$ & $\begin{array}{l}1.44 \mathrm{E}- \\
06\end{array}$ & -08 & 2.53E-09 \\
\hline : & 10 & 80 & 27.1 & $\begin{array}{l}68.2969 \\
1 \\
\end{array}$ & 5 & $\begin{array}{l}9.23 \mathrm{E}- \\
05\end{array}$ & $\begin{array}{l}1.64 \mathrm{E}- \\
06\end{array}$ & $.58 \mathrm{E}-08$ & 2.79E-09 \\
\hline 这 & 11 & 83929 & 27.1 & $\begin{array}{l}67.9754 \\
9\end{array}$ & 4.840360 & $\begin{array}{l}9.17 \mathrm{E}- \\
05\end{array}$ & $\begin{array}{l}1.82 \mathrm{E}- \\
06\end{array}$ & 25E-08 & 3.01E-09 \\
\hline 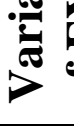 & 2 & 0.08 & 27.2 & $\begin{array}{l}67.6943 \\
4\end{array}$ & 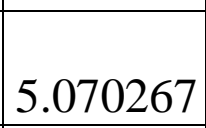 & $\begin{array}{l}9.12 \mathrm{E}- \\
05\end{array}$ & $\begin{array}{l}1.98 \mathrm{E}- \\
06\end{array}$ & 8.84E-08 & $3.20 \mathrm{E}-09$ \\
\hline 氙 & 1 & 355 & 6.14504 & $\begin{array}{l}13.8063 \\
2\end{array}$ & ) & \begin{tabular}{|l}
0.0003 \\
07 \\
\end{tabular} & $\begin{array}{l}3.34 \mathrm{E}- \\
05\end{array}$ & 000000 & 0.000000 \\
\hline 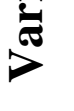 & 2 & .023890 & 4.557 & $\begin{array}{l}15.9152 \\
6\end{array}$ & $19.0+3$ & 0.0002 & $\begin{array}{l}3.86 \mathrm{E}- \\
05\end{array}$ & $4.39 \mathrm{E}-07$ & 1.70E-08 \\
\hline
\end{tabular}




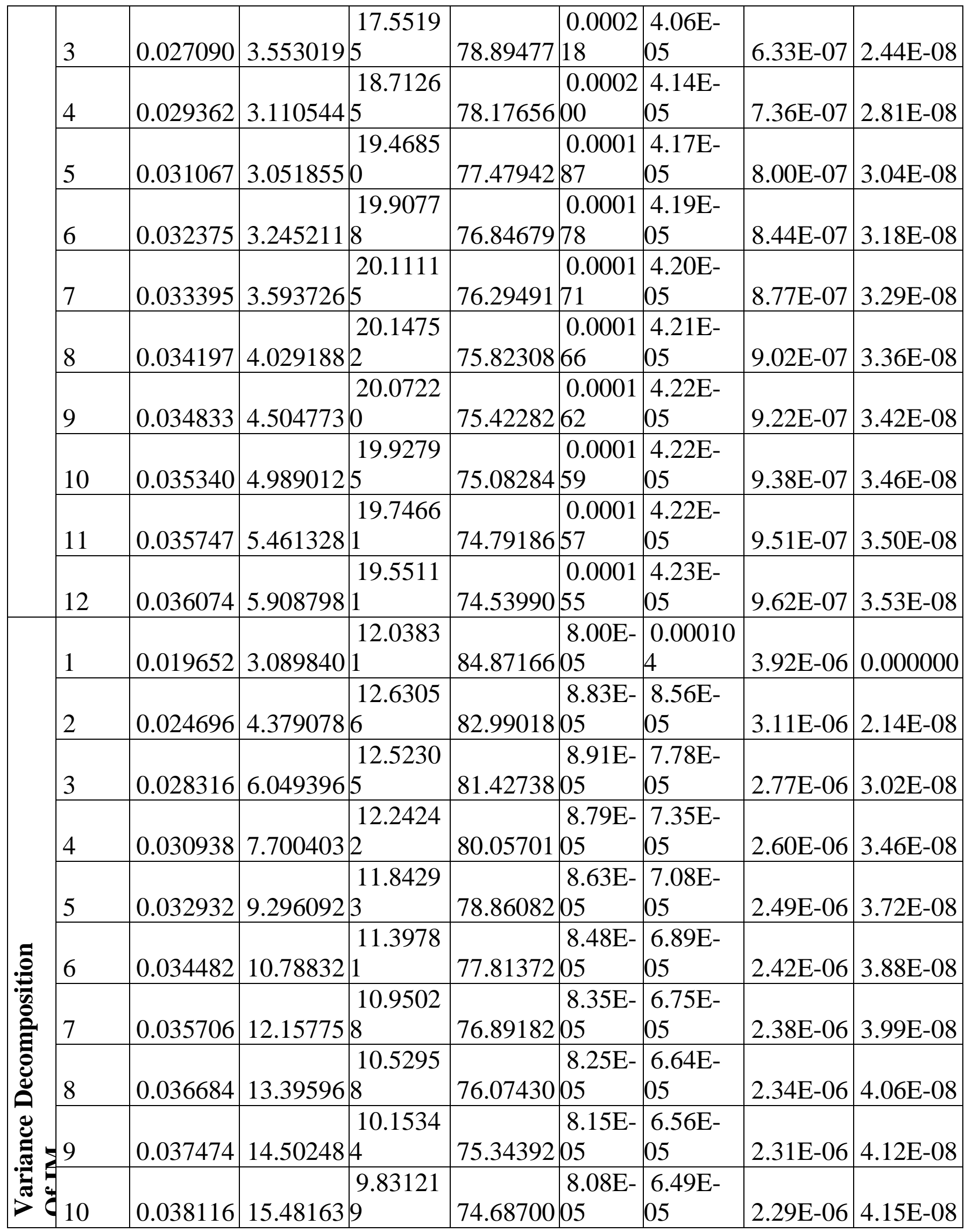




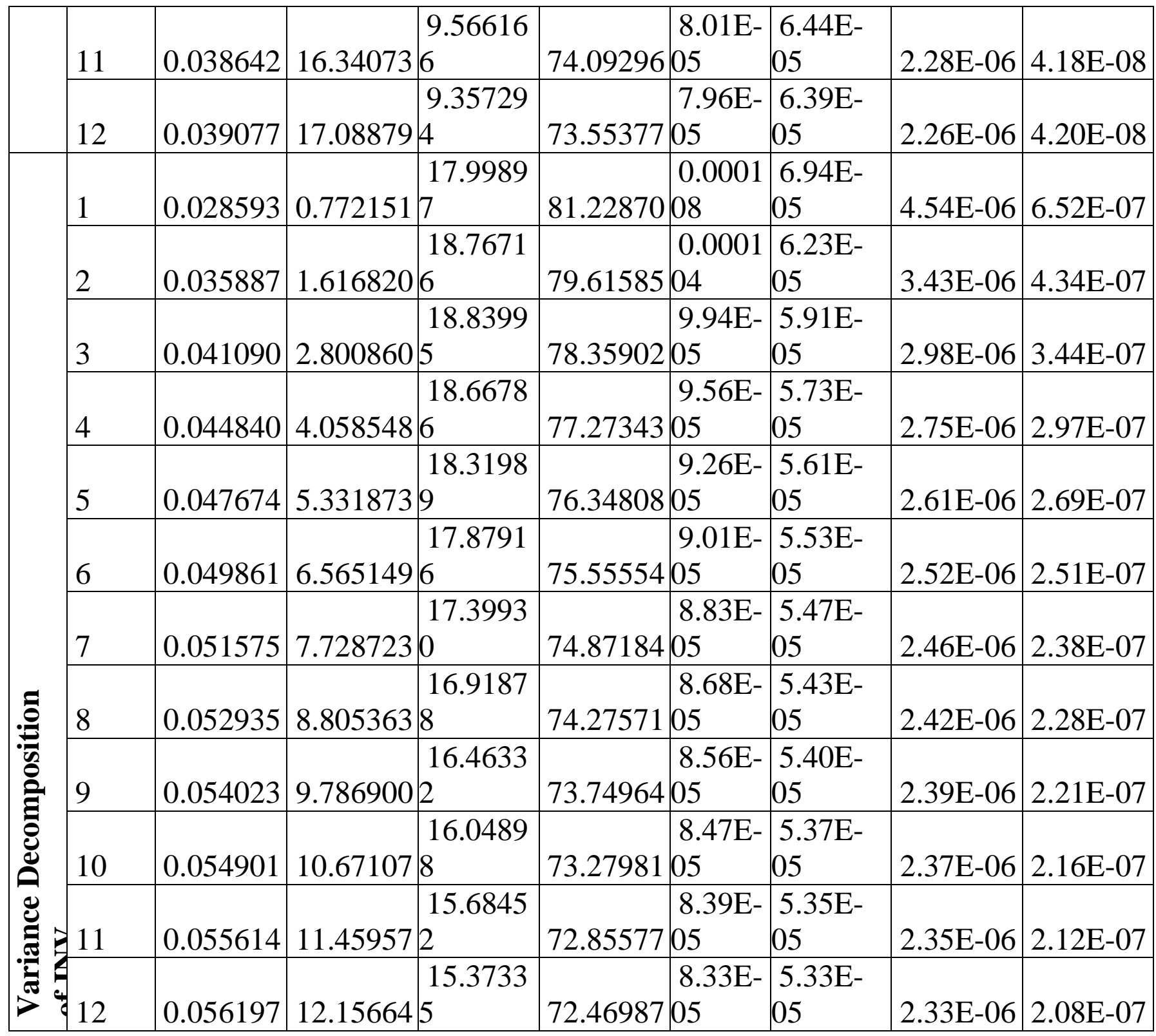

Source: Author using Eviews 10.

The Variance Decomposition is an alternative method to the impulse response functions to examine effects of shocks to the dependent variables by determining how much of variance for any variable, is explained by innovations to every explanatory variable. Usually, own series shocks explain most of the error variance, although the shock will also affect other variables. The result of Variance Decomposition on each endogenous variables of the model in response to one standard deviations of COV19 is presented in table 6.

The Variance Decomposition of CPI shows fluctuations in the first month were due to the innovation of the same variable with $100 \%$, and the effect of the rest of the variables on CPI began in the second month. The contribution of COV19 in fluctuations of CPI increased from February to December to be $13 \%$ of variance of CPI. 
The Variance Decomposition of COV19 shows fluctuations in the variable were due to the innovation of the same variable COV19 with $99 \%$ in the first month and continued to the last month to be $96 \%$.

The Variance Decomposition of EMP shows the COV19's contribution in fluctuations of EMP in the first month with $66 \%$ and continued during the period to reach 56\% in December, and EMP contributed with $38 \%$.

The Variance Decomposition of EX indicates the COV19's contribution in fluctuations of EX in the first month with $71 \%$ and continued during the period to reach $67 \%$ in December 2020, and CPI contributed with $27 \%$ of EX's variance.

The Variance Decomposition of GOVEXP shows the COV19's contribution in fluctuations of GOVEXP starting from January with 13\% and continued during the period to reach 19\% in December 2020, and EMP contributed with 74\% of GOVEXP's variance.

The Variance Decomposition of IM shows the COV19's contribution in fluctuations of IM with $12 \%$ the first month and decreased to $9 \%$ in the last month, CPI contributed with $17 \%$ and EMP contributed with $73 \%$ of IM's variance.

The Variance Decomposition of INV indicates the COV19's contribution in fluctuations of INV with $18 \%$ the first month and decreased to $15 \%$ in the last month, CPI contributed with $12 \%$ and EMP contributed with $72 \%$ of INV's variance

Figure (14): Impulse Response Function 
Response to Cholesky One S.D. (d.f. adjusted) Innovations

Response of CPI to COV19

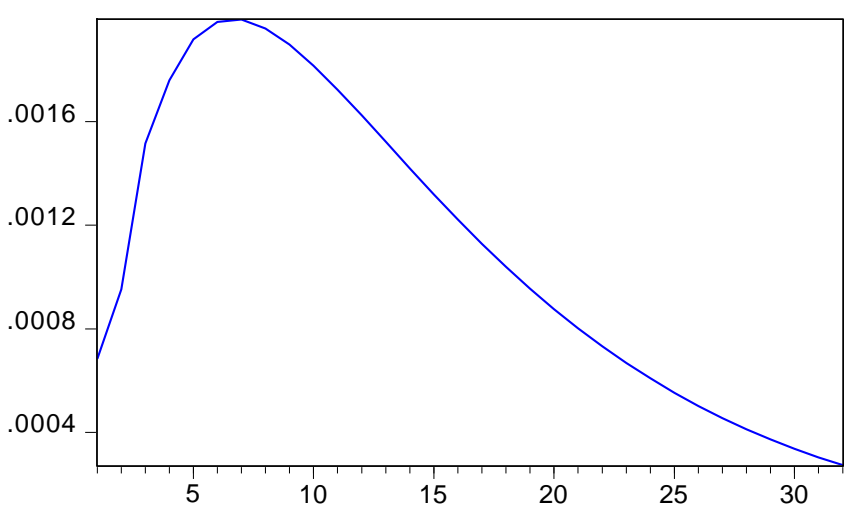

Response of EX to COV19

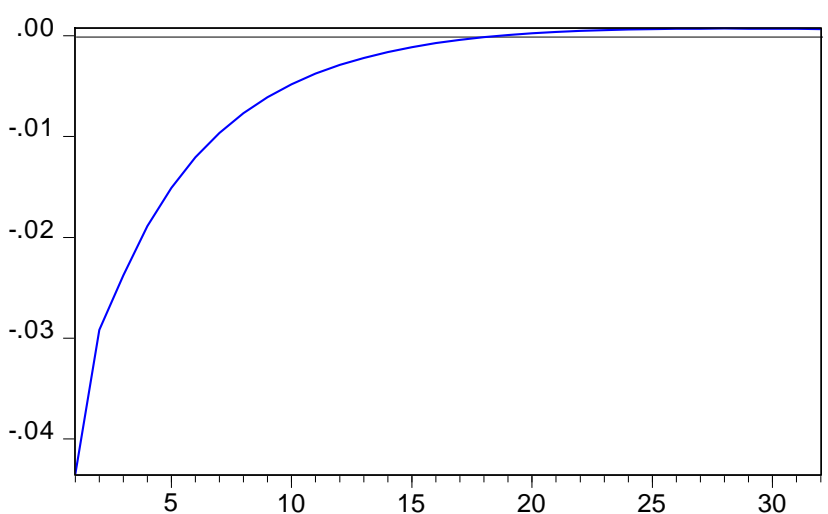

Response of IM to COV19

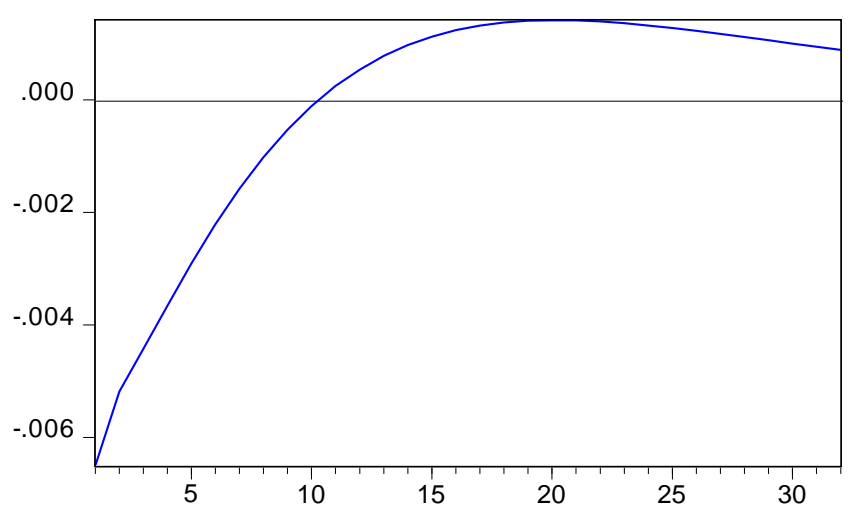

Source: Author using Eviews 10.
Response of EMP to COV19

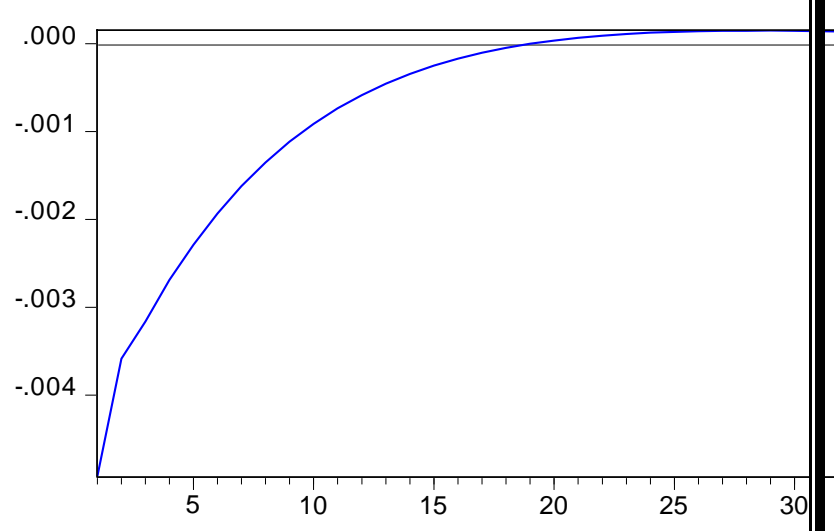

Response of GOVEXP to COV19

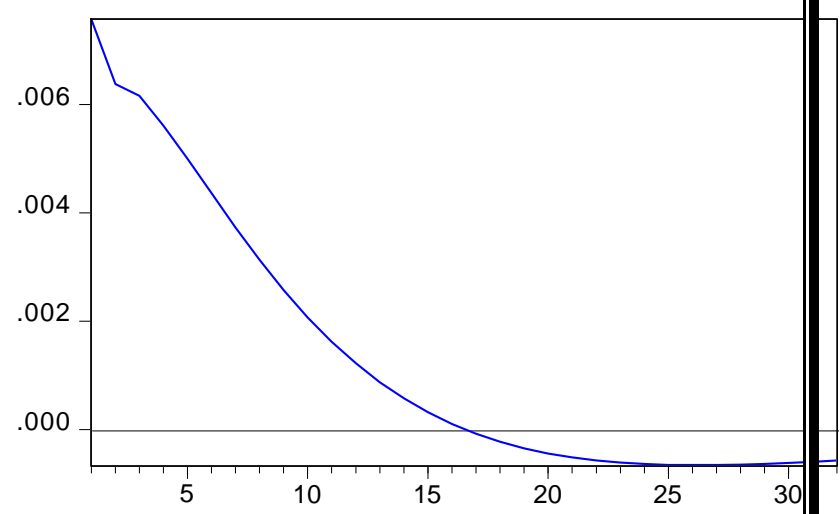

Response of INV to COV19

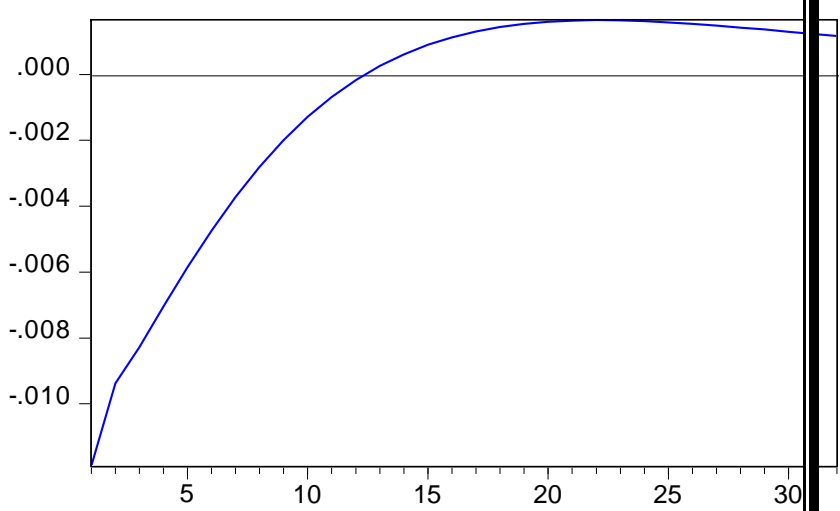

The Impulse response functions used to show the time path of the dependent variables in the PVAR, to shocks from all the independent variables. If equations are stable any shock should decline to zero, the shock produces an explosive time path. The result on Impulse Response Function of each 
endogenous variable in response to one standard deviations of COV19 is presented in figure 14.

The result of impulse response function reveals that the COV19 impact lasts at least 30 months (2 years and half) to shake the Arab economies. The VAR estimate indicates that COV19 uncertainty shock results a massive rise in CPI in the six months following the outbreak of the pandemic, then decrease CPI next 24 months.

The findings represent COV19 uncertainty shock results a decrease in EMP during 2 years following the outbreak of the pandemic then its effect will be zero. And the pandemic has the same effect on EX.

Regarding the effect on GOVEXP, COV19 uncertainty shock results a decrease in GOVEXP during 2 years following the outbreak of the pandemic. And make a decrease in IM during 10 months after the outbreak then beginning to rise during the next 20 months.

The impulse response function shows the COV19 results a decrease in INV in 12 months following the outbreak of the pandemic then induces a rise in INV until end of the period.

The findings revealed the breakups of the Arab economies; COVID 19 was a supply shock in its first-time impact, but quickly trans-passes to demand shock. the pandemic effect decreases employment, exports and government expenditure, but investment and imports decline up then show a slight increase, and results a massive rise in consumer price index then a slight decrease.

\section{5-SWOT Analysis of COVID 19 Impact on the Arab Countries} A- Strengths

The strengths achieved by the Arab countries from the repercussions of the Corona pandemic are as follows:

1- High profits in vital sectors

The sectors that become the most profitable as a result of the repercussions of the Coronavirus are; Pharmacy, sterilizers, electronic commerce, telecommuting, and logistics.

2- Saving and rationalizing expenditures

The Arab countries seek to save and rationalize expenditures, which saves public budgets to support many economic activities and face the repercussions of the Corona pandemic.

3- Reducing polluting emissions

The Arab countries are reducing the polluting emissions resulted from many industrial activities and the movement of transportation. In addition to give sufficient time to conduct regular maintenance of factory machinery and transportation networks.

B- Weaknesses 
the Arab countries achieved a set of weaknesses because of the spread of "COVID-19" virus, as follows: -

1- Poor health systems

Arab countries beard great costs in dealing with the Coronavirus, by providing necessary funding for the medical infrastructure to confront the pandemic, including a lot of medical, safety equipment and sterilization materials.

2- High loss rates in vital sectors

The sectors that cost huge loss as a result of the virus are: aviation, travel and tourism, hotel and hospitality, conferences, exhibitions and festivals, trade services, and oil.

3- Expatriate workers are harmed

The labor-exporting countries, including Egypt, have witnessed a slowdown in workers' remittances due to layoffs and delays in paying salaries in the countries in which they work.

4- Poor living conditions

The chronic symptoms of structural imbalance in some Arab countries have resulted in economic diseases, including over-consumption, poor saving and investment, and corruption, in addition to the imbalance of market structures, represented by poor distribution, class inequality, erosion of the middle class, and spread of poverty and unemployment.

3- Low oil prices

Oil prices have decreased in the Arab Gulf states, as falling fuel prices is the main driver of sharp decline in the free-market commodity price index, as it decreased by $33.2 \%$ in March 2020.

4- Poor information infrastructure

Data in some Arab countries are still being collected on paper rather than digital, so it is difficult for citizens to deal directly with service providers as a result of outbreak of the disease.

5- High unemployment rates

The unemployment rates have increased, especially for some sectors as the tourism, which contributes at rates ranging between 12 to $19 \%$ of the GDP in some Arab countries that are global tourist destinations.

6- Difficulty in coordinating economic policies

The Arab countries vary in degrees of economic growth, in addition to the different economic systems, which leads to the difficulty of coordinating economic policies.

7- Economic and financial dependency

Many Arab countries are economically dependent on developed countries, and this dependence makes private interests more urgent.

8- The weakness of the competitive structure of the Arab economies 
There is a similar competing industry with low productivity and high production expenditures that only produce under protection with weak production base in addition to external orientation of the development strategy in the Arab countries.

\section{C- Opportunities}

The Arab countries can exploit many opportunities resulted from the Corona virus at the external level, as follows:

1- The prosperity of the medical industries

Arab countries can benefit from prosperity of the medical industries, because the total imports of medical products during 2019 amounted to 2 trillion \$, including the European Union trade, which represents 5\% of the total world trade. Arab countries can invest this to engage in medical industries and benefit from the increasing global demand on them.

2- Digital finance to stop the spread of COVID-19

The digital finance is considered as a tool to stop the spread of COVID19; along with their partners, are implementing procedures to transfer a larger volume of payments using the mobile.

3- Enhancing intra-Arab trade

The Arab countries can turn inward to enhance intra-trade, especially in pharmaceuticals and basic foods, in addition to start manufacturing medicines, which leads to lowering their prices, and boosts trade between Arab countries. Also, the Arab countries can support local investments in the pharmaceutical industry, it helps ensure the quality and safety of imports, and contributes to financial sustainability with the increase in import bills across the Arab countries.

4- Increasing the most attractive investment opportunities

The most attractive investment opportunities for Arab countries are investment in the energy sector and the transport sector, in addition to investment in education, building and managing economic zones, and specific service activities, such as information and communication technology services, financial and health services, and professional services.

5- Creating a balanced and integrated development strategy among the Arab countries

The priority of Arab countries is for strategic dimensions such as food security, infrastructure, and human capital, in addition to partnership with the private sector in planning and implementing these investments.

D- Threats

There are a number of threats as a result of the repercussions Corona virus, as follows: -

1- Slowdown in the global economic growth 
The slowdown in global economic growth and the disruption of global trade led to lower rates of growth. The global economic slowdown reached $2 \%$ for 2020, and its costs amounted to 1 trillion \$, resulted in the decrease in oil prices.

2- Poor financial market performance

The losses resulted in a global economic depression, as investors' withdrawal their capital from investment in the financial markets to protect their investments from economic fluctuations resulted from corona pandemic.

4- Lack of competencies in the labor market

There is a temporary shortage of competencies in the labor market, lead to shortage of production in the public and private sectors.

Table (7): Results of the SWOT Analysis

\begin{tabular}{|c|c|}
\hline Strengths & Weaknesses \\
\hline $\begin{array}{l}\text { Saving and rationalizing } \\
\text { expenditures in budgets }\end{array}$ & Poor health systems \\
\hline Reducing polluting emissions & High loss rates in some sectors \\
\hline $\begin{array}{l}\text { Implementing and conducting } \\
\text { periodic maintenance }\end{array}$ & Poor living conditions \\
\hline High profits in vital sectors & Weak information infrastructure \\
\hline $\begin{array}{l}\text { Reducing fuel consumption and } \\
\text { energy resources }\end{array}$ & Low oil prices \\
\hline $\begin{array}{l}\text { Expanding the umbrella of social } \\
\text { insurance }\end{array}$ & $\begin{array}{l}\text { Difficulty coordinating economic } \\
\text { policies }\end{array}$ \\
\hline $\begin{array}{l}\text { Increasing support for the medical } \\
\text { sector and equipping hospitals }\end{array}$ & Economic and financial dependency \\
\hline $\begin{array}{l}\text { Expanding the provision of services } \\
\text { electronically }\end{array}$ & $\begin{array}{l}\text { Weakness of the competitive } \\
\text { structure }\end{array}$ \\
\hline $\begin{array}{l}\text { New technologies and business } \\
\text { models }\end{array}$ & $\begin{array}{l}\text { Restriction of travel and movement } \\
\text { for individuals and goods }\end{array}$ \\
\hline $\begin{array}{l}\text { Restructure supply chains and move } \\
\text { towards decentralization in } \\
\text { manufacturing }\end{array}$ & $\begin{array}{l}\text { Sanitary isolation measures and the } \\
\text { closure of markets and service } \\
\text { centers. }\end{array}$ \\
\hline Opportunities & Threats \\
\hline Booming medical industries & Slowing global economic growth \\
\hline $\begin{array}{l}\text { Digital Finance to Stop the Spread } \\
\text { of COVID-19 }\end{array}$ & $\begin{array}{l}\text { Reduced inflow of foreign direct } \\
\text { investment }\end{array}$ \\
\hline $\begin{array}{l}\text { Promote intra-Arab trade and } \\
\text { Strengthening Arab relations }\end{array}$ & $\begin{array}{l}\text { poor performance of the financial } \\
\text { markets }\end{array}$ \\
\hline $\begin{array}{l}\text { Increasing the most attractive } \\
\text { investment opportunities }\end{array}$ & $\begin{array}{l}\text { Lack of competencies in the labor } \\
\text { market }\end{array}$ \\
\hline
\end{tabular}




\begin{tabular}{|l|l|}
\hline $\begin{array}{l}\text { Creating a balanced and integrated } \\
\text { development strategy }\end{array}$ & New waves of Corona virus \\
\hline $\begin{array}{l}\text { Diversify export partners and } \\
\text { sources of financing }\end{array}$ & \\
\hline
\end{tabular}

Source: By Author

6- Mechanisms to confront COVID19 in the Arab Countries

The corona pandemic can be dealt with in two phases: a phase of containment and stabilization, followed by a phase of recovery, there is a crucial role for both public health and economic policies. These measures can help avoid a more severe and longer-term recession and pave the way for the economy to recover. Increased spending on health care is necessary to ensure that health care systems have the initial capacity and resources. This requires fundamental measures directed through public finances, monetary policy and the financial sector to maintain economic links between employment, companies, lenders and borrowers, thus preserving the integrity of the economic and financial infrastructure. In addition to digital technology can be used to provide targeted support to those who need it. ${ }^{239}$

The corona crisis can be classified as a double crisis, it is an external and internal crisis, it is a crisis of demand and supply, and it is a market crisis and a government crisis. it is difficult for countries to rely on the market because of the market collapses and it is difficult to rely on demand because the crisis extended both sides of demand and supply, so these mechanisms are divided into three groups, as follows:

A- At the national level

The efforts and measures taken by the Arab countries in order to reduce the economic repercussions of the crisis, and call on Arab countries to continue: 1- Supporting national banks to implement the procedures for postponing the payment of customer debt installments, restructuring the credit facilities granted, providing concessional financing for small and medium enterprises to maintain support for effective aggregate demand, and helping companies bear the consequences of the pandemic.

2- Increase the coverage of social protection programs and facilitate access to them to ensure the population most exposed to risks is not neglected. The implementation of these measures will require a combination of domestic and foreign resources.

3- Follow expansionary monetary policies, by reducing interest rates and the cash reserve ratio for bank grants, as well as reducing fees, profit rates, and commissions that financial institutions charge from their clients, especially small borrowers, and giving banks greater flexibility to provide direct credit to the health services sector. 
4- Increasing allocations for education, scientific research and health in the public budgets of Arab countries. The percentage of spending on scientific research in Arab countries does not exceed 1.5\%, so it is important to increase allocations for these sectors to achieve the desired results in the Arab countries.

B- The Arab Financing Institutions

1- Establishing an Arab Crisis Fund similar to the Small and Medium Enterprises Support Fund. To manage the funds in accordance with the purpose to lend procedures in the fund are more flexible and expeditious, avoid routine, and provide loans to the private sector affected by the pandemic with easy terms and low interest rates.

2- Forming crisis task forces from the relevant joint Arab action institutions and Arab financing institutions whose task is monitoring the impact of corona pandemic on Arab countries, in order to prepare sectoral studies and suggest the necessary policies.

3- Maximize benefit from the trade financing mechanisms available with the Arab Trade Finance Program to mobilize funds and support credit lines directed to financing intra-Arab trade.

4- Coordinating between the existing regional funds by directing part of their investments towards the health sector and small and medium enterprises; Providing dependency allowances for those who have lost their jobs; building stocks of food and medicine; Designing and financing appropriate programs to support Arab exporters and importers.

Conclusion

The study determined the COVID 19 pandemic impacts on the Arab countries, through macroeconomic variables like investment, employment, imports, exports, prices, and government expenditure, using the Bayesian Vector Auto-regressions model PVAR. As well as the SWOT Analysis method to analyze the repercussions of Coronavirus on the Arab economies. The Arab countries need a help of bilateral creditors from advanced economies and the international financial institutions, so multilateral cooperation is necessary. In addition to exchanging equipment and specialized expertise to strengthen health care systems, a global effort must be made to ensure that rich and poor countries have access to the required drugs and vaccines for the COVID-19 virus as soon as they are reached. The international community will also need to intensify financial aid to many emerging market and developing economies.

Finally, building an Arab stock of personal protective equipment, to protect individuals and institutions, preventing more severe economic suffering and creating favorable conditions for recovery.

\section{Endnotes}

The United Nations Industrial Development Organization www.unido.org 
International Energy Agency, www.iea.org

International Labor Organization, www.ilo.org

International Civil Aviation Organization, www.icao.int

International Monetary Fund: World Economic Outlook, (Washington DC, IMF, June 2020(

The United Nations Conference on Trade and Development (UNCTAD) https://unctad.org/en/Pages/coronavirus.aspx

Ibid

The World Bank https://blogs.worldbank.org/ar/arabvoices/coronavirus-potential-effectsmiddle-east-and-north-africa

American Chamber of Commerce in Egypt http://www.amcham.org.eg

The Arab Monetary Fund, https://www.amf.org.ae

Ibid

The Arab Monetary Fund, the Economic Outlook report 2020, www.atfp.org.ae

Ibid

International Monetary Fund: Regulatory and Supervisory Response to Deal with Coronavirus Impact, (Washington DC, IMF, 2020(

Socioeconomic Impact of COVID-19: Policy Briefs, www.unescwa.org

The Arab Monetary Fund, https://www.amf.org.ae

International Monetary Fund: Options to Support the Incomes of Informal Workers During COVID-19, (Washington DC, IMF, 2020(

Socioeconomic Impact of COVID-19: Policy Briefs, www.unescwa.org

The International Labor Organization www.ilo.org

International Monetary Fund: Are Macro and Credit Policies Enough?, (Washington DC, IMF, 2020(

Jake Bright, Africa turns to mobile payments as a tool to curb COVID-19, March 26, 2020 https://techcrunch.com/2020/03/25/african-turns-to-mobile-payments-as-a-tool-to-curbCOVIDeferrer=aHR0cHM6Ly93d3cuZ29vZ2xlLmNvbS8\&guce_referrer_sig=AQAAACa3 gjAoGQwkzEfHmgZTH_9e921A9nN0wr_5avnk8F2JiY0ywLQHFBGPUMK60r9pyrd7BYh TtbTYvA_hF44FNyw8DgSVNPCA0bR_qcCwGLJ1vz75O5tp75PNdLewyhCkJ

Moody's Investor Services http://www.moodys.com 
The Arab Tourism Organization and the Arab Civil Aviation Organization, https://www.arab-tourismorg.org

The International Air Transport Association (IATA), www.iata.org

International Monetary Fund: Export and Import Price Indexes in Response to COVID-19, (Washington DC, IMF, 2020(

International Monetary Fund: Banking Sector Regulatory and Supervisory Response to Deal with Corona virus Impact, (Washington DC, IMF, 2020(

International Monetary Fund: Global Financial Stability Report, Markets in the Time of COVID-19, (Washington DC, IMF, April 2020(

UNCTAD: The Need to Protect Funded during and after the COVID-19 Crisis, (New York: United Nations, April 2020( 